\title{
Natural Gas Hydrates on the North Slope of Alaska
}

\author{
Final Report
}

T.S. Collett

January 1991

Work Performed Under Contract No.: DE-AI21-83MC20422

For

U.S. Department of Energy

Office of Fossil Energy

Morgantown Energy Technology Center

Morgantown, West Virginia

By

U.S. Geological Survey

Menlo Park, Califomia 


\section{DISCLAIMER}

This report was prepared as an acoount of work sponsored by an asency of the United States Government. Neither the United States Government nor any azency thereof, nor any of their employees, makes any warranty, express or implied, or assumes any legal linbility or responsibility for the accuracy, completeness, or usefuiness of any information, apparatus, product, or process discloced, or represents that its use would not initringe privately owned rights. Reference herein to any specific commercial product, process, or service by trade name. trademark, manufacturer, or othenwise does not necessarily constitute or imply its endorsement, recommendation, or favoring by the Unized States Government or any agency thereof. The views and opinions of authors ex. pressed herein do not necessarily state or refloct those of the United States Government or any agency thereol.

This report has been reproduced directly frem the best available copy.

Available to DOE and DOE contractors from the Office of Scientific and Technical Information, P.O. Box 62, Oak Ridge, TN 37831; prices available from $(615) 576-8401$, FTS 626-8401.

Available to the public from the National Technical Information Service, U.S. Department of Commerce, 5285 Port Royal Rd., Springfield, VA 22161. 
Natural Gas Hydrates on

$\mathrm{DOE} / \mathrm{MC} / 20422--2968$

DE91 002054 the North Slope of Alaska

Final Report

T.S. Collett

Work Performed Under Contract No.: DE-AI21-83MC20422

\author{
For \\ U.S. Department of Energy \\ Office of Fossil Energy \\ Morgantown Energy Technology Center \\ P.O. Box 880 \\ Morgantown, West Virginia 26507-0880
}

\author{
By \\ U.S. Geological Survey \\ 345 Middlefield Road \\ Menlo Park, California 94023
}

January 1991 


\begin{abstract}
Gas hydrates are crystalline substances composed of water and gas, mainly methane, in which a solid-water lattice accommodates gas molecules in a cage-like structure, or clathrate. These substances of ten have been regarded as a potential (unconventional) source of natural gas. Significant quantities of naturally occurring gas hydrates have been detected in many regions of the Arctic including Siberia, the Mackenzie River Delta, and the North Slope of Alaska. On the North Slopis, the methane-hydrate stability zone is areally extensive beneath most of the coastal plitin province and has thicknesses as great as 1,000 meters in the Prudhoe Bay area.

Gas hydrates have been identified in 50 exploratory an 1 production wells using well-log responses calibrated to the response of an interval in one well where gas hydrates were recovered in a core by ARCO Alaska and EXX ON. Most of these gas hydrates occur in six laterally continuous Upper Cretaceous and lower Tertiary sandstone and conglomerate units; all these gas hydrates are geographically restricted to the area overlying the eastern part of the Kuparuk River Oil Field and the western part of the Prudhoe Bay Oil Field. The volume of gas within these gas hydrates is estimated to be about $1.0 \times 10^{12}$ to $1.2 \times 10^{12}$ cubic meters ( 37 to 44 trillion cubic feet), or about twice the volume of conventional gas in the Prudhoe Bay Field.

Geochemical analyses of well samples suggest that the identified hydrates probably contain a mixture of deep-source thermogenic gas and shallow microbial gas that was either directly converted to gas hydrate or first concentrated in existing traps and later converted to gas hydrate. The thermogenic gas probably migrated frorn deeper reservoirs along the same faults thought to be migration pathways for the large volumes of shallow, heavy oil that occur in this area.
\end{abstract}




\section{TABLE OF CONTENTS}

Introduction

Previous North Slope gas-hydrate studies

Factors that affect gas-hydrate stability

Geology of the North Slope gas-hydrate reservoirs

Regional geology

Geology of the Prudhoe Bay-Kuparuk River area

North Slope gas hydrate distribution

Northwest Eileen State-2 gas hydrate occurrences

Gas hydrate well-log evaluation techniques 11

Well log inferred gas hydrate occurrences

Gas hydrate reservoir properties. 20

Potential gas-hydrate traps 21

Gas-hydrate resource estimate 25

Geologic history of gas hydrates 26

Source of the gas within the gas hydrates 26

Origin and timing of gas hydrate formation 28

Conclusion 29

References cited 29 


\section{LIST OF FIGURES}

Eigure

Page

1 Gas hydrate stability diagram from northern Alaska 2

2a Map of the North Slope physiographic provinces 4

2b Base map of North Slope study area 5

3 Isopach map of the North Slope methane-hydrate stability field 8

4 Geologic correlation section between the Kuparuk River Unit 1D-8 and Prudhoe Bay Unit Q-3 wells of northern Alaska

5 Pressure core-barrel test of the cored gas hydrate occurrences in the Northwest Eileen State-2 well

6 Plot of well logs from the cored gas hydrate interval in the Northwest Eileen Stite-2 well

7 Cross-section depicting the lateral and vertical extent of gas hydrates and underlying free-gas occurrences in the Prudhoe Bay-Kuparuk River area

8a Composite map of all six gas-hydrate/free-gas Units in the Prudhoe Bay-Kuparuk River area

8b Maps depicting the distribution of each gas-hydrate/free-gas Unit in the Prudhoe Bay-Kuparuk River area

9 Plot of neutron log calculated and core derived porosities for the Prudhoe Bay-Kuparuk River area

10 Composite Pickett cross plot depicting the degree of gas-hydrate saturation in the log inferred gas-hydrate-bearing Units

11 Schematic cross section through the Prudhoe Bay-Kuparuk River area illustrating spatial relations between the in-situ gas hydrates, free-gas, oil, Eileen fault zone, base of ice-bearing permafrost, and the gas-hydrate stability field. 


\section{LIST OF TABLES}

Table

Page

1 Geochemical analysis of gas obtained from the Northwest Eileen state-2 well 13

2 North Slope wells with inferred gas hydrate occurrences 16

3 Reservoir data and calculated volume of gas within the gas hydrates of the Prudhoe Bay-Kuparuk River 


\section{INTRODUCTION}

Large amounts of natural gas, composed mainly of methane, can occur in sediment in the form of gas hydrates. These substances are solids, composed of rigid cages of water molecules that trap molecules of gas under specific pressure and temperature conditions. The structure of the ice-like framework or lattice depends on the shape and size of the gas molecules which are in contact with the water. Hydrates are characterized by two distinct structures known as Structure I and Structure II (Hitchon, 1974); Structure I gas hydrate is more commonly expected in nature. At standard conditions (STP), one volume of Structure I methane hydrate may contain as much as 164 volumes of methane gas (Davidson and others, 1978); because of this large gas storage capacity, gas hydrates may represent an important source of natural gas. For a more complete review of gas hydrate molecular structure see Sloan (1990; p. 24-66).

Gas hydrates have been known as laboratory curiosities since 1810 (reviewed by Sloan, 1990). Detailed s:adies of gas hydrates and their physical properties were not undertaken until Hammerschmidt (1934) published data pertaining to the plugging of natural-gas pipelines due to gas-hydrate formation. The geologic occurrence of gas hydrates has been known since the mid1960 's, when gas-hydrate accumulations were discovered in the USSR (reviewed by Makogon, 1981). Gas hydrates occur in sedimentary deposits under conditions of pressure and temperature that are present in permafrost regions (figure 1) and beneath the sea in outer continental margins (reviewed by Kvenvolden and McMenamin, 1980). Geologic, geochemical, and geophysical evidence of gas hydrates in both the marine and permafrost environments include; (1) high concentrations of methane in sedimentary deposits, (2) gas released from cores in the amounts expected for decomposing gas hydrate, (3) seismic anomalies that can be explained by the properties of sediments containing gas hydrates, and (4) geophysical well-log responses indicative of gas-hydrate-bearing sediments.

Cold surface temperatures at high latitudes on Earth are conducive to the development of onshore permafrost and gas hydrate in the subsurface. Cias hydrates are known to be present in the western Siberian platform (Makogon and others, 1972) and are believed to occur in other permafrost areas of northern U.S.S.R., including the Tinnan-Pechora province, the eastern Siberian craton, and the northeastern Siberian and Kamchatka areas (Cherskiy and others, 1985). Permafrost-associated gas hydrates are also present in the North American Arctic (Kvenvolden and Grantz, 1990). Well-log responses, attributed to the presence of gas hydrates, have been obtained in about a fifth of the wells drilled in the Mackenzie Delta, and in the Arctic Islands over half of the wells are inferred to contain gas hydrates (Bily and Dick, 1974; Judge, 1988). Direct evidence for gas hydrates on the North Slope of Alaska comes from a core-test, and indirect evidence comes from drilling and open-hole industry well logs which suggest the presence of numerous gas hydrate layers in the area of the Prudhoe Bay and Kuparuk River oil fields (Collett, 1983; Collett and others, 1988). The combined information from Arctic gas-hydrate studies shows that in permafrost regions, gas hydrates may exist at subsurface depths ranging from $\approx 130$ to $\approx 2,000 \mathrm{~m}$.

Because large quantities of gas hydrates are widespread in permafrost regions they may be a potential energy resource. Estimates of the amoint of gas within continental gas hydrates range from $1.4 \times 10^{13}$ to $3.4 \times 10^{16}$ cubic meters $\left(5.0 \times 10^{2}\right.$ to $1.2 \times 10^{6}$ trillion cubic feet) (adapted from Potential Gas Committee, 1981). Gas hydrates also represent a significant drilling and engineering hazarl. Soviet, Canadian, and American researchers (Bily and Dick, 1974; Franklin, 1980; Makogon, 1981; Sloan, 1990) have described numerous problems associated with gas hydrates, including blowouts and casing failures. As exploration and development activity continues in high latitude arctic environments, the frequency of gas hydrate induced problems will likely increase. 


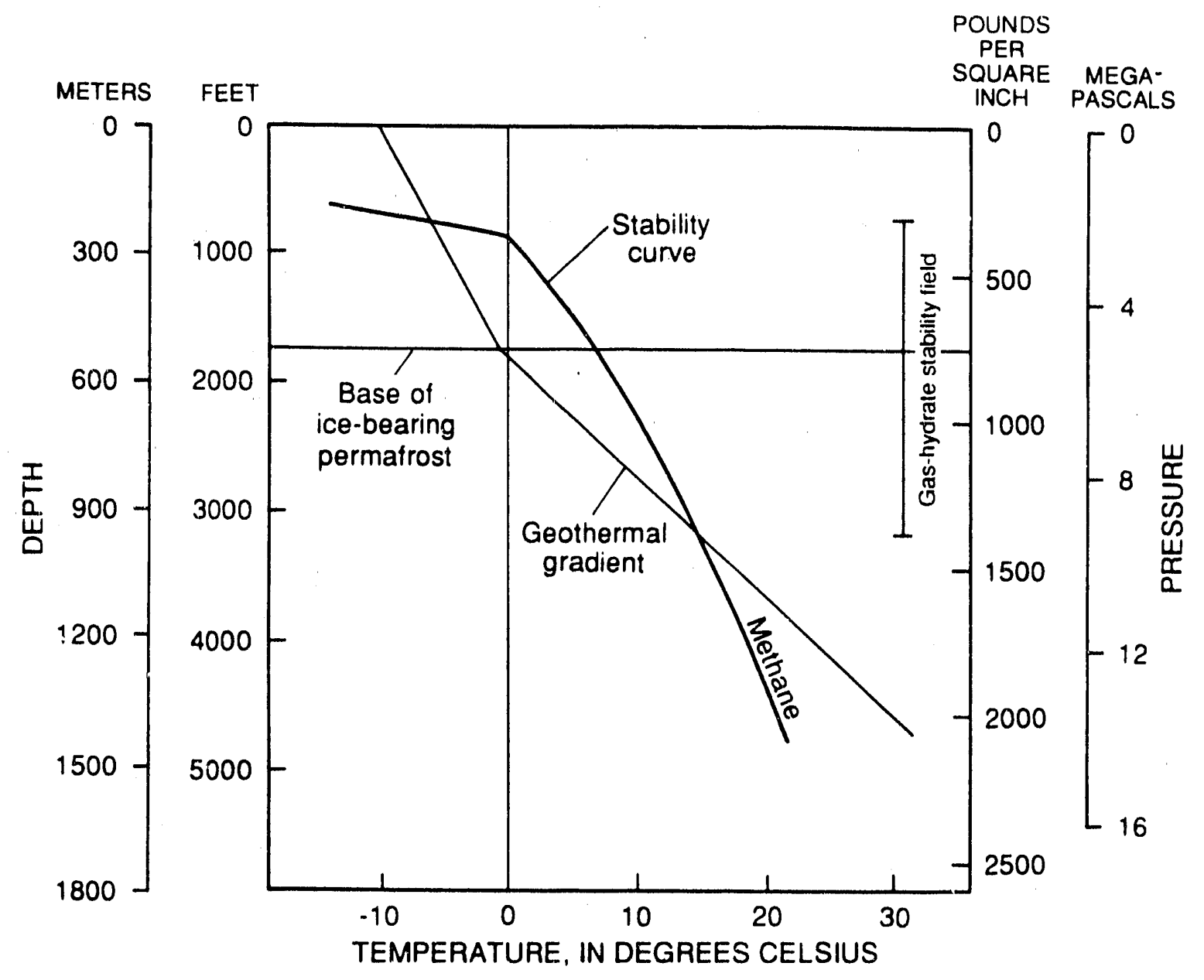

Figure 1. Example of the depth-temperature zone in which gas hydrates are stable in a permafrost region (adapted from Collett, 1983). 


\section{Previous North Slope Gas-Hydrate Studies}

On the North of Alaska several completed studies infer that gas hydrates may be present in the National Petroleum Reserve in Alaska (NPRA) and in the area of the Kuparuk River Oil Field. Pratt (1979) concluded from the review of pertinent geologic data that the most favorable areas for gas hydrates in NPRA are near (1) Point Barrow, (2) Tunalik, and the (3) Colville Delta (figures $2 a$ and $2 b$ ). Galate and Goodman (1982) examined 17 wells from NPRA for evidence of in-situ gas hydrates. For this study, they used all available records such as drilling plans, well histories, daily drilling reports, mud reports, coring information, and well logs. Of the 17 wells investigated, they reported that 3 showed significant evidence for gas hydrates, and 5 showed some evidence of gas hydrates (figure 2b). Detailed analysis of a series of open-hole well logs from 125 wells in the area of the Prudhoe Bay and Kuparuk River oil fields suggest the presence of 102 gas-hydrate occurrences in 32 different wells (Collett, 1983). In Collett (1983) it was concluded that the inferred gas hydrates occur within relatively porous, discrete sedimentary units and in many wells in multiple zones; the individual zones range from 2 to $28 \mathrm{~m}$ in thickness. Most of the gas-hydrate occurrences appear to be geographically restricted to the Kuparuk River Oil Field, west of Prudhoe Bay (figure $2 b$ ).

The primary objectives of this study were to assess the possible geologic controls on the occurrence of gas hydrates, estimate the volume of gas trapped within the gas hydrates, and explain the history of gas-hydrate formation on the North Slope. To reach these objectives, all available geologic data from the North Slope have been studied, including, well logs, core data, drill-cuttings, drilling reports, and seismic records. This paper begins with a review of the geologic parameters that control gas-hydrate stability, and is followed by a description of the stratigraphic framework within the area of suspected gas hydrate occurrences. The main body of the paper describes the gas hydrate occurrences in the Prudhoe Bay-Kuparuk River area. The paper concludes with a gas hydrate resource appraisal and a description of a geologic model which explains the history of gas-hydrate formation on the North Slope.

\section{FACTORS THAT AFFECT GAS-HYDRATE STABILITY}

Two primary factors affect the stability of in-situ gas hydrates--geothermal gradient and gas chemistry. Other factors which are difficult to quantify and often have little affect are pore-fluid salinities, pore-pressures, and reservoir-rock grain sizes (Holder and others, 1987; Collett and others, 1988; Sloan, 1990).

On the North Slope, subsurface temperature data are available from high-resolution, equilibrated well-bore surveys in $\mathbf{4 6}$ wells, and from estimates based on identification of the base of ice-bearing permafrost in 102 other wells. Beginning in 1958, a series of 46 North Slope wells considered to be in or near thermal equilibrium, have been surveyed with high-resolution temperature devices (Lachenbruch and others, 1982; Lachenbruch and others, 1987). Geothermal gradients needed to predict the depth and thickness of the gas-hydrate stability field can be interpreted directly from these recorded equilibrated temperature profiles. To augment the temperature data base, a new method of evaluating local geothermal gradients has been developed. In this method, a series of well-log picks for the base of the ice-bearing permafrost from 102 wells have been used, along with regional temperature constants derived from the high-resolution stabilized well-bore temperature surveys to extrapolate temperature data. For a complete description of this method see Collett and others (1988). A comparison of geothermal gradients calculated from the high-resolution temperature surveys and projected from known ice-bearing permafrost depths generally agree favorably over most of the North Slope with values in the icebearing sequence ranging from $\approx 1.5^{\circ} \mathrm{C} / 100 \mathrm{~m}$ in the Prudhoe Bay area to $\approx 4.5^{\circ} \mathrm{C} / 100 \mathrm{~m}$ in east central NPRA. The calculated and projected geothermal gradients below the ice-bearing sequence range from $\approx 1.6^{\circ} \mathrm{C} / 100 \mathrm{~m}$ to $\approx 5.2^{\circ} \mathrm{C} / 100 \mathrm{~m}$.

The next most important variable when considering gas hydrate stability conditions is the chemistry of the included gas. The analysis of mud-log gas-chromatographic data from 320 wells 


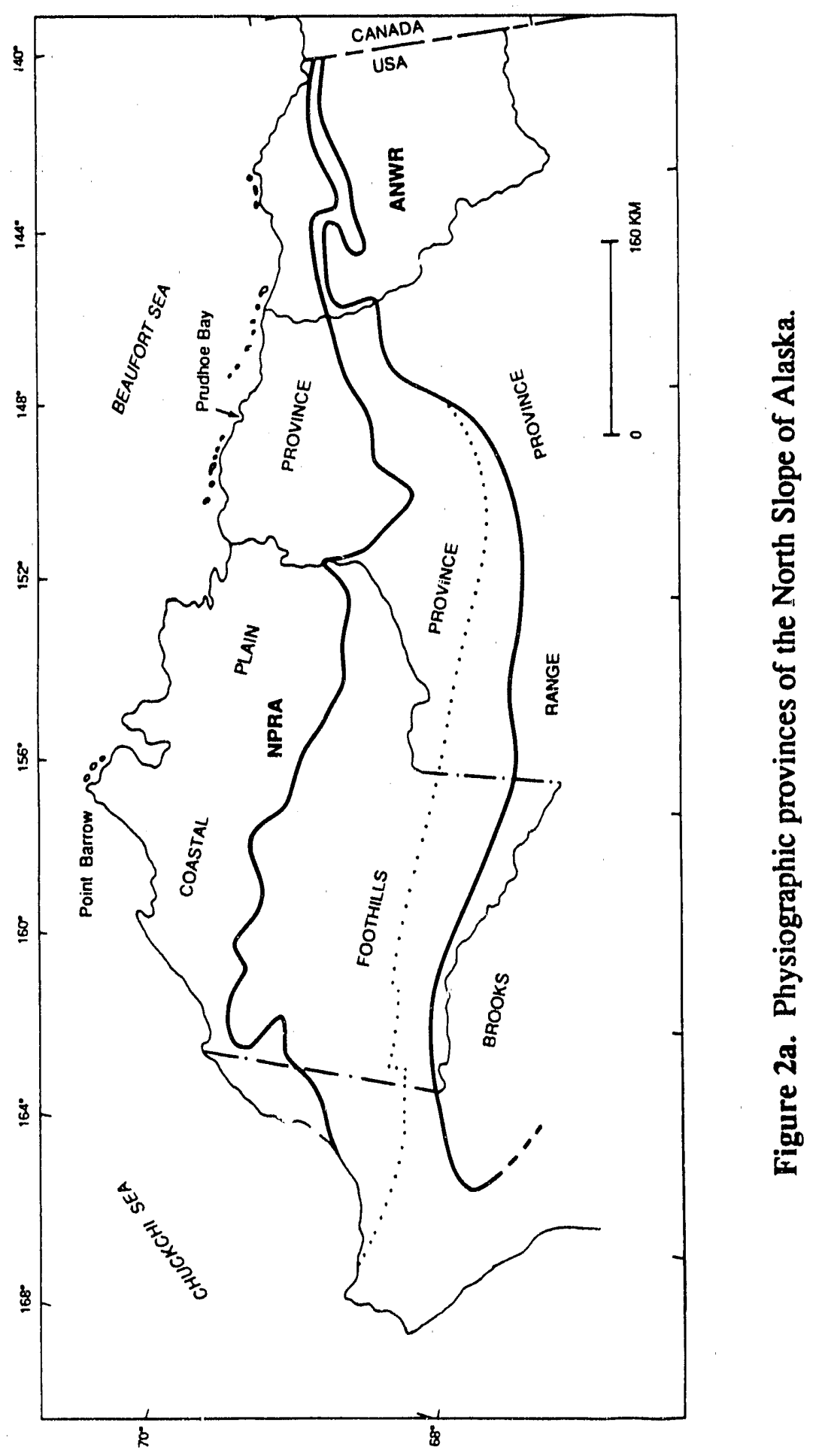




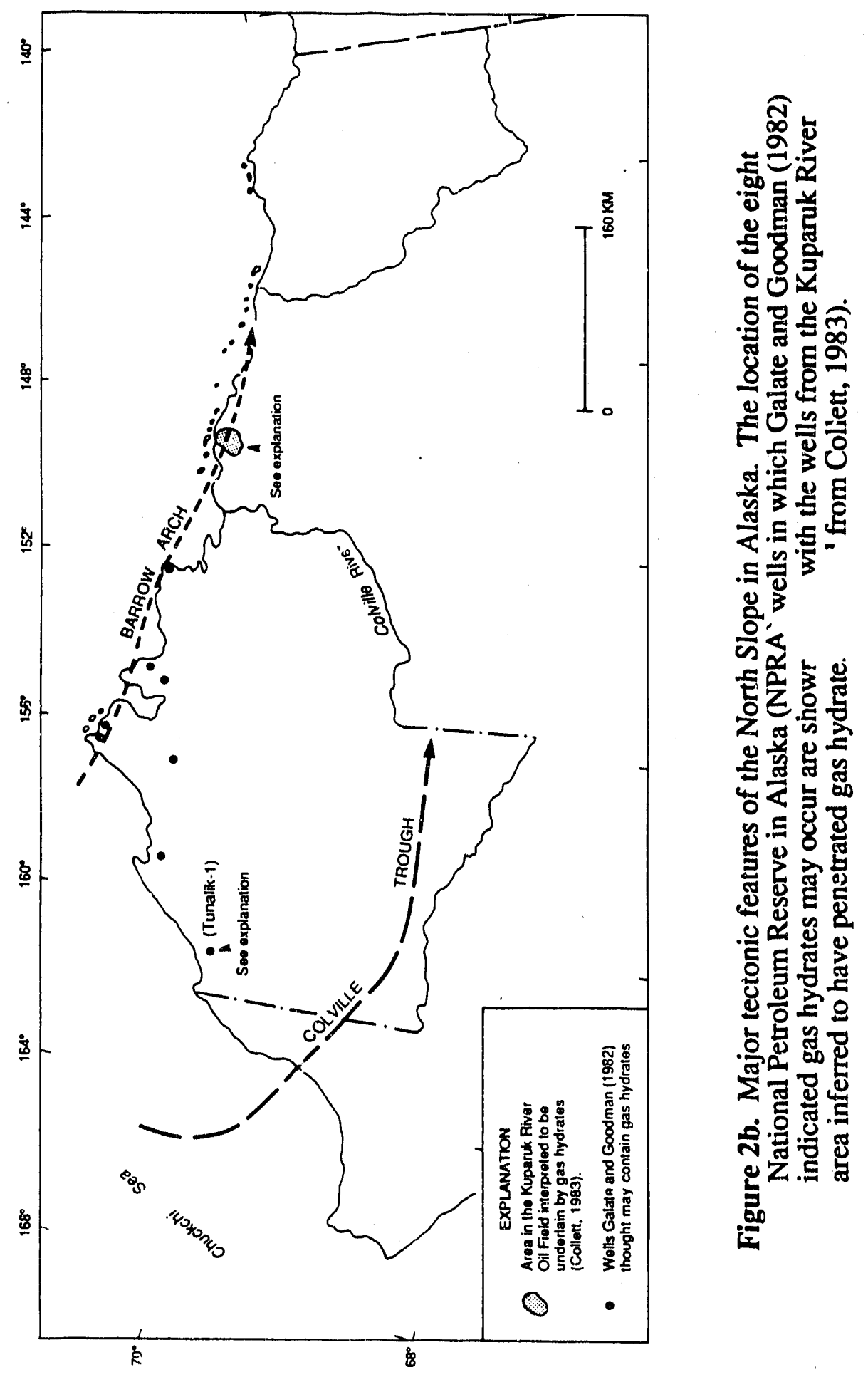


suggest that methane is the dominant hydrocarbon gas in the near-jurface $(0-1,520 \mathrm{~m})$ sediments of the North Slope. Analysis of the gas believed to evolved from cored gas hydrates in the Northwest Eileen State-2 well (to be discussed later), located in the Prudhoe Bay Oil Field, also suggest that the in-situ hydrates are composed of mostly methane; hov/ever, in several analysis nitrogen was detected and this gas inhibits hydrate formation (Collett, and others, 1988). The gas analysis from the Northwest Eileen State 2 well are inconsistent; therefore, the validity of the geochemical data from this well is uncertain. Because or the lack of data and the uncertainty in reported geochemical arialysis, the gas hydrate stability caiculations in this paper have been made assuming a pure-methane chemistry.

Salt, such as $\mathrm{NaCl}$, when added to a gas hydrate system, lowers the temperature at which gas hydrates form (Evrenos and others, 1971). On the North Slope, analyse: of 55 water samples collected during petroleum formation testing in rock units from below the permafrost sequence $(\approx 400$ to $=2,000 \mathrm{~m})$ indicate that (bulk) pore-water salinities range from 0.5 to $19.0 \mathrm{ppt}$. Spontaneous potential well-log calculations within the same interval confirm that rore-water salinities are low, ranging from 2 to i9 ppt. Analyses of cores from within the ice-bearing sequence of the BF-12,-10-14A well, located in the Prudhoe Bay Oil Field, indicate that salinities within the sands of the ice-bearing permafrost sequence are very low, ranging from 0.15 to 0.50 ppt (Howitt, 1971). The low salinities in the ice-bearing horizons may be caused by connate fluvial water, meteoric recharge, salt rejection during freezing, or a combination of these factors. The maximum recorded salinity of $19.0 \mathrm{ppt}$ would shift the methane hydrate stabiling curve approximately $-1.0^{\circ} \mathrm{C}$, which is considered negligible. Therefore, the thermal effect of the dissolved salts on gas-hydrate stability was not included in the gas-hydrate stability determinations in this paper.

Most gas-hydrate stability studies assume that the subsurface pore-pressure gradient is hydrostatic $(9.795 \mathrm{kPa} / \mathrm{m} ; 0.433 \mathrm{psi} / \mathrm{ft})$. Fore-pressure gradients greater than hydrostatic will correspond to relatively higher pore-pressures with depth and a thicker gas-hydrate stability field. Pore-pressure gradients calculated from shut-in pressures recorded during shallow $(=400$ to $\approx 2,000 \mathrm{~m}$ ) drill-stem testing in wells from the North Slope range from 9.3 to $11.2 \mathrm{kPa} / \mathrm{m}$, with an average gradient of $9.7 \mathrm{kPa} / \mathrm{m}(0.43 \mathrm{psi} / \mathrm{ft})$, near hydrostatic (data from State of Alaska Oil and Gas Conservation Commission well files). To further evaluate pore-pressures, well logs from 22 North Slope wells have been used to study over-burden compaction. As rocks, particularly shales, are subjected to increasing over-burden pressures, they are compacted and subsequent transit-time velocities and gamma-ray well-log values ir rease with depth because of increasing formation densities. If a rock interval is over-pressur is will resist compaction and can be identified on acoustic transit-time and gamma-ray logs by a departure of the log curve from a trend line (Zoeller, 1984). Within the near-surface $(0-1,500 \mathrm{~m})$ sediments of the North Slope, however, no significant pore-pressure discontinuities were observed. Pore-pressures in wells studied here are a product of a hydrostatic pore-pressure gradient; therefore, the gas-hydrate stability determinations in this paper assume a hydrostatic pore-pressure gradient $(9.795 \mathrm{kPa} / \mathrm{m} ; 0.433 \mathrm{psi} / \mathrm{ft})$.

The effect of grain-size variations on gas hydrate equilibrium is unclear. It is known from studies of permafrost, however, that variations in grain sizes affect the freezing point of ice (Anderson and others, 1973; Osterkamp, 1975; Osterkamp and Payne, 198i). Particles with large surface area relative to grain size, such as clay, can reduce the freezing point of water by several degrees Celsius (Anderson and others, 1973; Collett and Bird, 1988). A similar relation may exist between grains of high surface area and gas-hydrate equilibrium temperatures; however, as of this time it is impossible to quantify the effect of grain-size on gas-hydrate stability due to the lack of prior quantitative studies.

The methane-hydrate stability curve used for this study was based on a stability model and experimental results reviewed by Lewin and Associates, Inc., (1983). The stability curve has been simplified as a function of temperature into two equations:

$$
\begin{aligned}
& \mathrm{P}(\mathrm{kPa})=\exp \left[14.7170+1886.79 / \mathrm{T}^{\circ} \mathrm{K}\right] \quad\left(\text { from } 248 \text { to } 273^{\circ} \mathrm{K} \text { or }-25 \text { to } 0^{\circ} \mathrm{C}\right) \\
& \mathrm{P}(\mathrm{kPa})=\exp \left[38.9803+8533.80 / \mathrm{T}^{\circ} \mathrm{K}\right] \quad\left(\text { from } 273 \text { to } 298^{\circ} \mathrm{K} \text { or } 0 \text { to } 25^{\circ} \mathrm{C}\right. \text { ) }
\end{aligned}
$$


The $\mathrm{P}(\mathrm{kPa})$ represents the dissociation or formation pressure of a methane hydrate at a given temperature $\mathrm{T}\left({ }^{\circ} \mathrm{K}\right)$. For the purpose of calculating subsurface gas-hydrate stability conditions, the variable $\mathrm{T}\left({ }^{\circ} \mathrm{K}\right)$ represents the equilibrium temperature in Kelvin at any given depth. The depth values of the stability curve can be calculates. by means of the equation by converting the derived pressure $\mathrm{P}(\mathrm{kPa})$ using the local pore-pressure gradient.

The following assumptions have been made in determining the extent of the gas-hydrate stability field on the North Slope: (1) The hydrates contain only methane gas, (2) geothermal gradient ranges from $\approx 1.5^{\circ} \mathrm{C} / 100 \mathrm{~m}$ to $\approx 4.5^{\circ} \mathrm{C} / 100 \mathrm{~m}$ within the ice-bearing permafrost siquence, and below the ice-bearing sequence the geothermal gradient ranges from $\approx 1.6^{\circ} \mathrm{C} / 100 \mathrm{~m}$ to $=5.2^{\circ} \mathrm{C} / 100 \mathrm{~m}$, (3) pore-waters are fresh (no dissolved salt), (4) pore-pressure gradient is hydrostatic, and (5) reservour rock grain-size has no effect on gas-hydrate stability. The calculated depth to the top of the methane-hydrate stability field ranges between $\approx 210$ and $\approx 240$ meters. The calculated total thickness of the methane-hydrate stability field is isopached in figure 3 which shows that the methane-hydrate stability field on the North Slope is thiskest in the Prudhoe Bay area, with calculated values slightly greater then $1,000 \mathrm{~m}$.

\section{GEOLOGY OF THE NORTH SLOPE GAS-HYDRATE RESERVOIRS}

\section{Regional Geology}

The North Slope of Alaska, encompasses all of the land north of the Brooks Range drainage divide and is generally subdivided into three physiographic provinces, from south to north: the Brooks Range, the foothills, and the coastal plain (figure 2a). Oriented in a subparallel east-west direction, these provinces reflect underiying geologic trends. The three main structural elements that compose the North Slope are the Brooks Range orogen, the Colville trough, and the Barrow arch, all of which correspond generally to the respective physiographic provinces (figures $2 \mathrm{a}$ and $2 \mathrm{~b}$ ). The Barrow arch is a broad regional basement high that separates the Colville trough from the present Arctic Ocean basin. The basement, at relatively shallow depths along the Barrow arch, slopes gently southward and reached a depth of about $10,000 \mathrm{~m}$ in the Colville trough. The southern part of the trough is overridden by the Brooks Range orogen, which contains basement and younger rocks.

The geolngy and petroleum geochemistry for rocks on the North Slope of Alaska are described in considerable detail in a number of publications (Morgridge and Smith, 1972; Lerand, 1973; Grantz and others, 1975; Jones and Spears, 1976; Seifert and others, 1979; Magoon and Claypool, 1985; Carman and Hardwick, 1983; Tailleur and Weimer, 1987; Bird and Magoon, 1988; and Gryc, 1988). The sedimentary rocks of the North Slope can be conveniently grouped into three sequences that indicate major episodes in the tectonic development of the region and, to a degree, its lithologic character. Defined on the basis of source area, these sequences, proposed by Lerand (1973) and applied to northern Alaska by Grantz and others (1975) are, in ascending order, the Franklinian (Cambrian through Devonian), the Ellesmerian (Mississippian through Jurassic), and the Brookian (Cretaceous to Holocene).

\section{Geology of the Prudhoe Bay--Kuparuk River area}

Previous North Slope studies (Cnllett, 1983; Collett and others, 1988) and preliminary review of all geologic data, indicate that gas hydrates occur only in rocks of the Sagavanirktok Formation (Brookian Sequence) and are limited to the area overlying the Prudhoe Bay and Kuparuk River oil fields. Gas hydrate distribution will be discussed later. Therefore, the discussion of the geologic setting of the potential gas-hydrate reservoirs will foc us on the local geology of the Sagavanirktok Formation within the Prudhoe Bay-Kuparuk River area.

The Sagavanirktok Formation consists of Upper Cretaceous and Tertiary shallow-marine shelf and delta plain deposits composed of sandstone, shale, and conglomerate whose provenance is the Brooks Range to the south. The areal distribution of the Sagavanirktok Formation is limited 


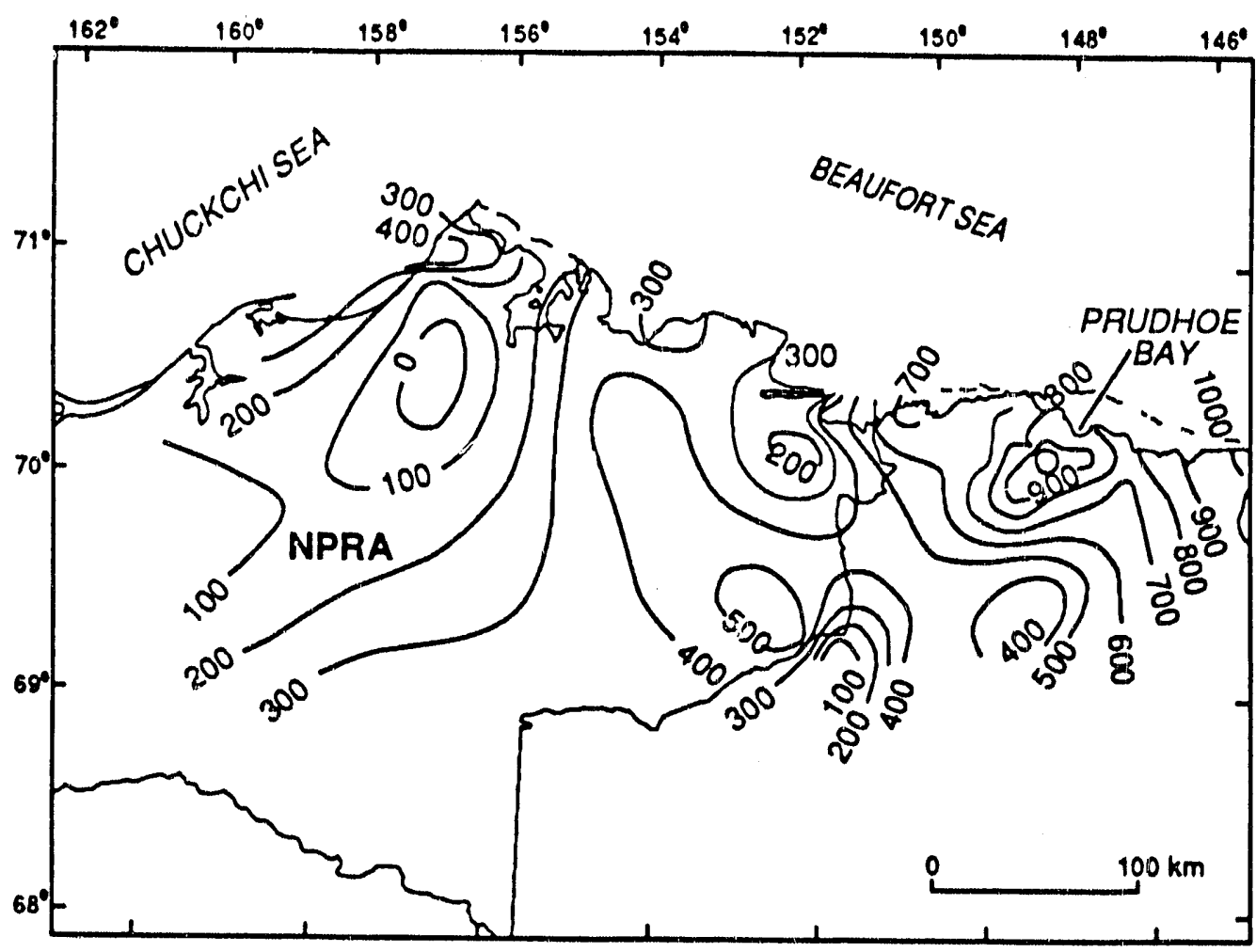

Figure 3. Isopach map of the central North Slope showing thickness (in meters) of the methanehydrate stability field. 
to the coastal plain of the eastern half of the North Slope and the adjacent continental shelf. The regional structure of the Sagav nirktok Formation in this area is a gentle $\left(1^{\circ}-2^{\circ}\right)$ northeasterlydipping monocline. The present regional northeast tilt is the combined res 6 of sediment loading and continued thermal subsidence of the Beaufort margin. In the study area the Sagavanirktok Formation thickens from southwest $(\approx 1,000 \mathrm{~m})$ to northeast $(\approx 2,000 \mathrm{~m})$, and conform: $\approx$ bly overlies marine shale of the Canning Formation. Depositional strike migrated from a nearly northsouth trend in Late Cretaceous time to its present west-northwest trend in about Eocene time.

Detailed well-correlation sections show the Sagavanir'tok Formation (figure 4) in this area consists of complexly interbedded marine and nonmarine deposits that include at least one regional unconformity. The lowermost sandstone sequence within the Sagavanirktok Formation includes the informally named West Sak and Ugnu sands. These oil-bearing horizons have been extensively described by Werner (1987) and are estimated to contain over 40 billion barrels of inplace oil. The Late Cretaceous West Sak interval represents transitional inner-shelf and delta-front deposits. The primary West Sak reservoirs are within the upper part of the sequence, which consists of two distinct and laterally extensive sandstone units. The West Sak interval is separated from the overlying Ugnu interval by a regionally extensive marine ( 30 to $45 \mathrm{~m}$ thick) mudstone. The Late Cretaceous-early Tertiary Ugnu interval (100 to $200 \mathrm{~m}$ thick) consists of a series of interbedded sandstone and mudstone units. Overlying the Ugnu interval is a 250 to $300 \mathrm{~m}$ thick nonmarine interval composed of numerous fining-upward channel and overbal.k siltstone and sandstone units. This nonmarine sequence is overlain by a 200 to $400 \mathrm{~m}$ thick interbedded sandstone and mudstone marine sequence that was deposited during a basin-wide marine transgression in Eocene time. This sequence thins southwesterly and laterally coarsens to a sandstone in the eastern part of the Kuparuk River field. The upper boundary of this marine sequence is an erosional unconformity. East of the Prudhoe Bay field, near the delta of the Sagavanirktok River, this unconformity has eroded part of the underlying marine sequence; however, to the southwest into the Kuparuk River area, the unconformity apparently disappears and the sequence becomes conformable. The rocks overlying the unconformity are generally of uniform composition both laterally and vertically in the section, and appear to have been deposited in a delta-plain environment. Individual sandstone units in this interval thicken to the northeast, which may represent the direction of the northeast-prograding deltaic depocenter. Other unconformities may occur within the Sagavanirktok Formation; however, with the present well-log data base it is not possible to identify any additional hiatuses.

In the Kuparuk River area, the Sagavanirktok Formation is cut by northwesterly-trending high-angle normal faults, generally downthrown to the east. A similar set of northwesterlytrending faults cut the older rocks in this area, suggesting a genetic linkage with the faults within the Sagavanirktok Formation. These faults are important in that they may serve as conduits for oil and gas migration from the underlying Prudhoe Bay field. Geochemical similarities sl'ggest that oils, and presumably the associated gas, within the Sagavanirktok Formation were "spilled" from the underlying Prudhoe Bay Sadlerochit Group reservoir as a consequence of regional tilting during middle to late Tertiary time (Carman and Hardwick, 1983).

\section{NORTH SLOPE GAS HYDRATE DISTRIBUTION}

\section{Northwest Eileen State-2 Gas Hydrate Occurrences}

The only confirmed natural gas hydrate on the North Slope was obtained in 1972, when ARCO and EXXON successfully recovered a core containing this substance (reviewed by Kvenvolden and McMenamin, 1980). The sample was from a depth of $:=666 \mathrm{~m}$ in the Northwest Eileen State-2 well, located within the Prudhoe Bay Oil Field (cored inte :val 664-667 m). The well was drilled with cool drilling muds in an attempt to reduce thawing of th: permafrost and decomposition of the in-situ gas hydrates. The core containing the sample of gas hydrate was recovered in a pressurized core barrel. The presence of gas in a hydrated state was confirmed by a 


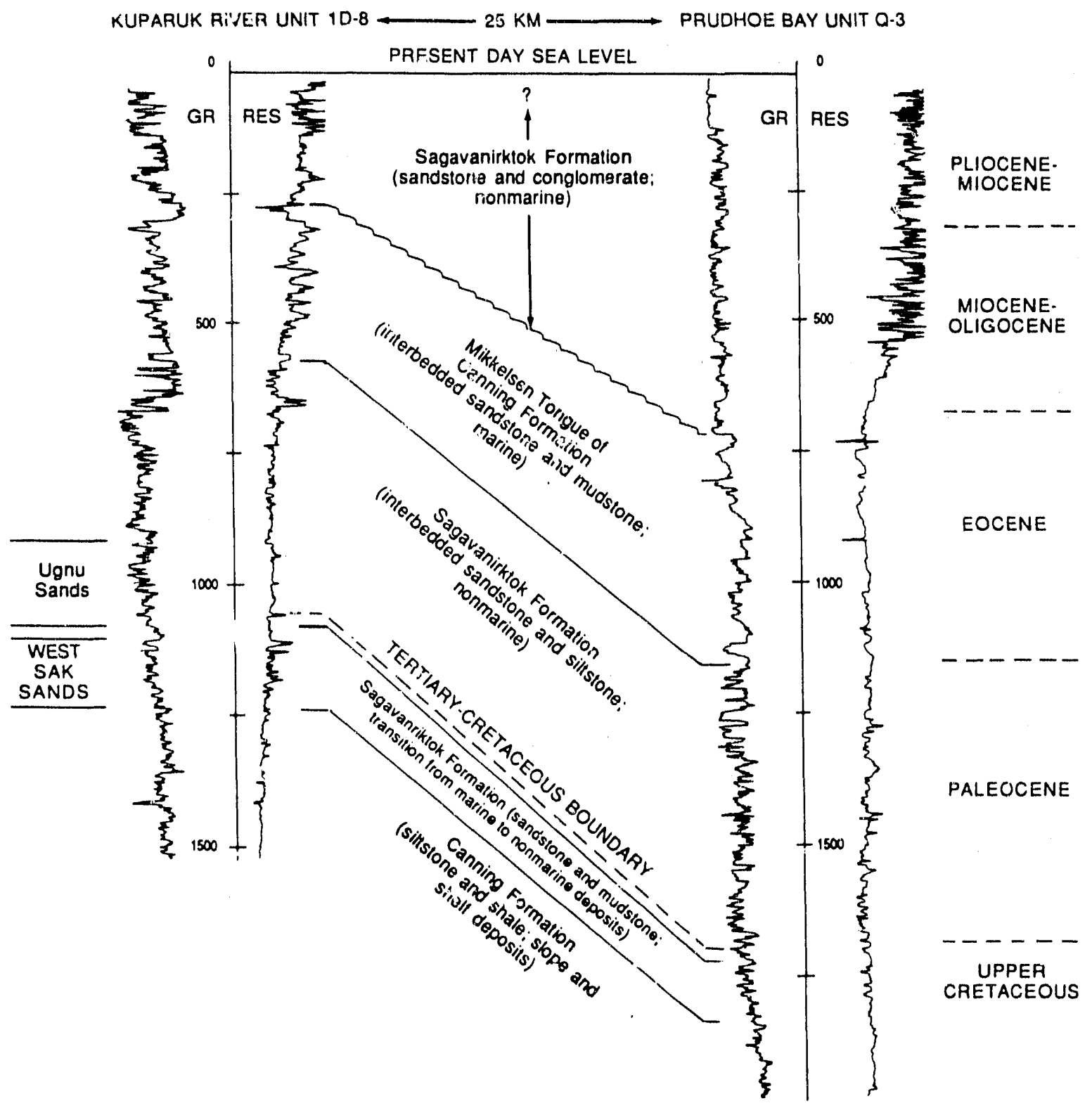

Figure 4. Correlation sections between Kuparuk River Unit 1D-8 and Prudhoe Bay Unit Q-3 wells showing stratigraphic relations and terminology of Brookian rocks used in this report. Depths on well logs are in meters measured from the kelley bushing. 
pressure test while the core was maintained in the core barrel at a temperature of about $1.0^{\circ} \mathrm{C}$ (figure 5). As the gas was withdrawn firom the core barrel, the pressure dropped, but it subsequently rose toward the theoretical gas-hydrate equilibrium pressure when the system was closed. If the core had containied only free-gas, the press are in the barrel would have decreased linearly as gas was withdrawri and the pressure would not have increased when the system was closed. This gas hydrate pressure response has been further discussed by Hunt $(1979, \mathrm{p} .167)$.

After completion of the Northwest Eileen State-2 well, the cored gas hydrate sequence was perforated and tested. A drill-sterm test of the perforated interval from 663 to $671 \mathrm{~m}$ flowed and swabbed gas at a maximum rate of 112 cubic meters per day $(3,960 \mathrm{cf} / \mathrm{d})$. Geochemical analyses (table 1) reveal that methane was the dominant gas recovered during the drill-stem test; about $93 \%$ of the flowed gas was methane, with the remaining 7\% being nitrogen. Analysis of four gas samples evolved from the hydrate-bearing core $(664-667 \mathrm{~m})$ suggest that the amount of methane in the hydrate sample ranged from 87 to 99 percent (written communication, P. Barker, ARCO Alaska Inc., Anchorage, Alaska).

Data from driller's and open-hole well logs also strongly suggested the presence of gas hydrates within the cored and tested interval of the Northwest Eileen State-2 well (figure 6). The occurrence of gas hydrates is suggested by the release of unusually large (up to $400,000 \mathrm{ppm}$ ) amounts of methane as indicated on the mud $\log$, and an increase in transit-time velocity and electrical resistivity as shown on the open-hole well logs.

\section{Gas Hydrate Well-Log Evaluation Techniques}

The confirmed gas hydrate occurrence in the Northwest Eileen State-2 well is an ideal starting point for the development of gas hydrate well-log evaluation techniques. The responses of the most diagnostic well logs within the confirmed gas-hydrate interval of the Northwest Eileen State-2 well (figure 6) are summarized below. For a complete review of gas hydrate well-log evaluation techniques see Collett and others (1988).

1. Dual Induction Log: There is a relatively high electrical-resistivity deflection on this $\log$ in a gas-hydrate zone, in comparison to that in a free-gas saturated horizon. If a rock were gas-hydrate saturated within the ice-bearing permafrost sequence, the resistivity response on the dual-induction log for the gas hydrate would not be significantly different from that in the surrounding ice-bearing permafrost. Below the base of the ice-bearing permafrost, however, the high-resistivity deflection associated with gas hydrate is distinct from the surrounding non-ice-bearing zones.

2. Acoustic Transit-Time Log: Within a gas hydrate there is a decrease in acoustic transittime in comparison to a unit saturated with either water or free-gas. Because the acoustic transit-time of ice is similar to that of gas hydrate, the acoustic log cannot be used to identify gas hydrates within the ice-bearing permafrost sequence.

3. Mud Log: On a mud log there is a pronounced gas kick associated with a gas hydrate due to hiydrate decomposition during drilling.

In this study, as with previous studies (Collett, 1983; Collett and others, 1988) the dualinduction and acoustic transit-time logs were consistently used to identify potential gas hydrates. The dual-induction and acoustic logs behave similarly within a unit either saturated with gas hydrate or ice. Hence, the occurrence of gas shows on the mud log produced from decomposing hydrate often provicies the only means of conclusively differentiating a gas hydrate from ice. Obviously, the recngnition of gas hydrates with well logs is not straight forward, and often the zones of yotential hydrate occurrence are not logged, or the quality of the logs may be poor. Anoth problem in the study of gas hydrates from well logs is the lack of prior quantitative work. 


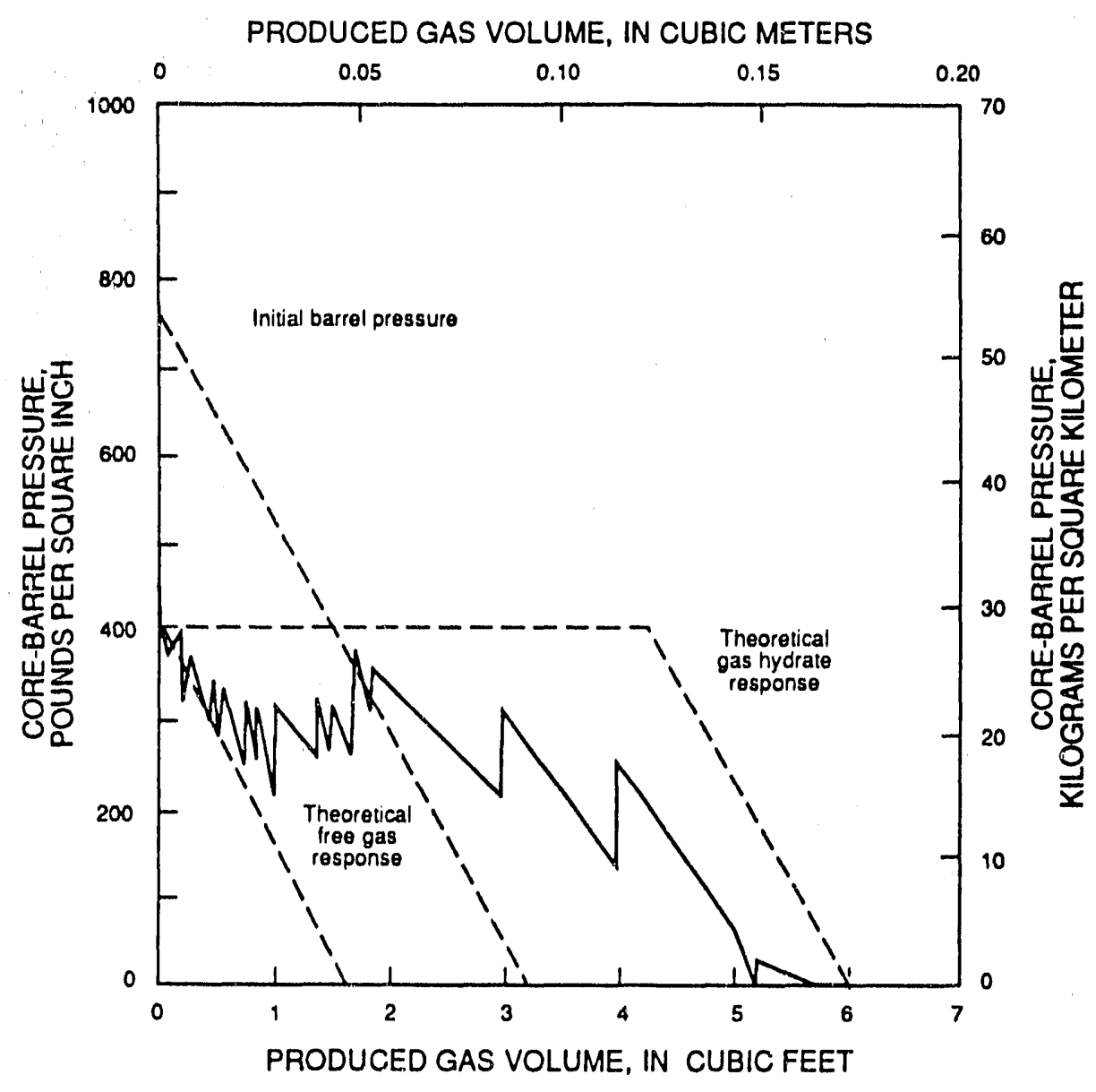

Figure 5. Pressure core-barrel experiment that proved the presence of gas hydrates in the Northwest Eileen State-2 well (written communication, P. Barker, ARCO Alaska Inc., Anchorage, Alaska). 


\begin{tabular}{|c|c|c|c|c|c|c|c|}
\hline $\begin{array}{c}\text { Sample } \\
\text { Type }\end{array}$ & $\begin{array}{l}\text { Interval } \\
\text { Depth (m) }\end{array}$ & $\begin{array}{c}\text { Carbon } \\
\text { JDioxide (\%) }\end{array}$ & $\begin{array}{c}\text { Oxygen } \\
1(\%) \\
\end{array}$ & $\begin{array}{r}\text { Nitroger } \\
(\%)\end{array}$ & $\begin{array}{c}\text { Methane } \\
(\%)\end{array}$ & $\begin{array}{c}\text { Ethane } \\
(\%)\end{array}$ & $\begin{array}{c}\text { Propane } \\
(\%) \\
\end{array}$ \\
\hline Core & $664-667$ & - & 0.52 & 12.53 & 86.95 & Trace & - \\
\hline Core & & - & 0.02 & 0.84 & 99.14 & Trace & - \\
\hline Core & 664-667 & - & 0.03 & 0.80 & 99.17 & Trace & - \\
\hline Core & $664-667$ & - & 0.05 & 1.46 & 98.49 & Trace & - \\
\hline Flow Test & $663-671$ & Trace & - & 7.19 & 92.79 & 0.02 & Trace \\
\hline Flow Tes & $663-671$ & Trace & - & 723 & 92.76 & 0.01 & Trace \\
\hline
\end{tabular}

Table 1. Geochemical analysis of gas samples obtained from the hydrate-bearing core (664-667 $\mathrm{m}$ ) and production flow test (663-671 m) in the Northwest Eileen State-2 well (written communication, P. Barker, ARCO Alaska Inc., Anchorage, Alaska). 


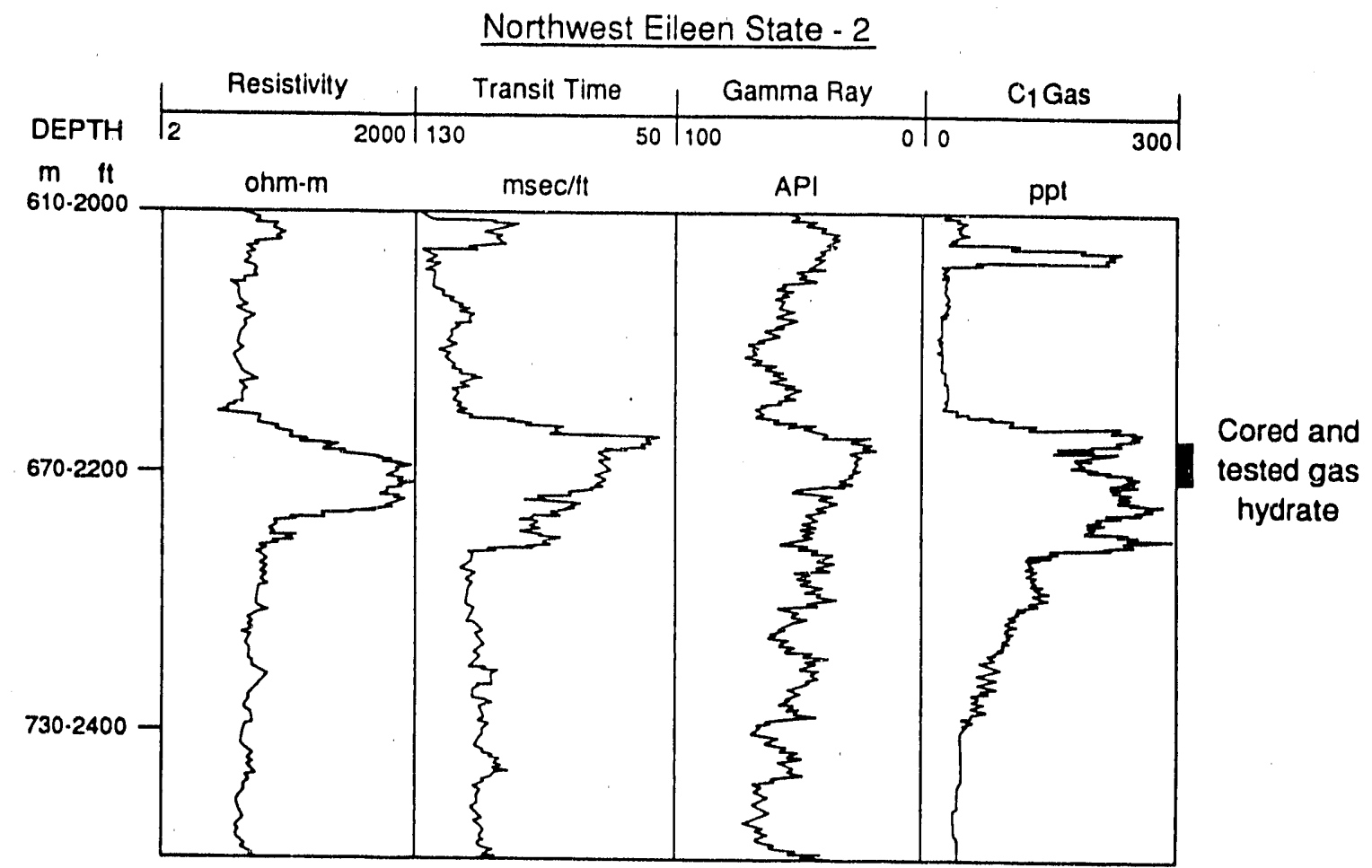

Tigure 6. Open-hole well logs and mud $\log$ from the cored $(664-667 \mathrm{~m})$ and production tested (663-671 m) gas hydrate interval in the Northwest Eileen State-2 well (table 1). 


\section{Well Log Inferred Gas Hydrate Occurrences}

For this study four-hundred and forty-five wells vvere examined for potential gas-hydrate occurrences. Most of the wells are from the Prudhoe Bay--Kuparuk River area; however, all wells from NPRA and most of the exploratory wells to the south and east of Prudhoe Bay have been reviewed. This analysis of all available data sources revealed that gas hydrates occur in 50 of the surveyed wells, all from the Prudhoe Bay-Kuparuk Riverr area (table 2).

Because gas hydrates can not be conclusively identified with well logs, the evaluation procedures must be qualified. Four qualifiers must be met before a particular horizon is identified as gas-hydrate bearing. These include (1) high resistivity relative to water (approximately 50 times greater); (2) short acoustic transit-time relative to water (an increase of approximately 40 microseconds per foot); (3) significant release of free-gas during drilling (recognized on the gas chromatograph of the mud log) with volumes of gas in the range of 30 to 100 parts per thousand; (4) a unit that is suspected of being gas-hydrate bearing must be laterally continuous in two or more wells. This last qualifier was only used in areas with a high density of wells. These parameters were selected because the cored gas hydrate in the Northwest Eileen State- 2 well exhibited similar well-log responses and appears to be laterally continuous in several surrounding wells.

The well log responses within the suspected gas-hydrate occurrences of NPRA as described by Galate and Goodman (1982) do not compare favorably with the well log responses within the cored gas-hydrate occurrence of the Northwest Eileen State-2 well. None of their suspected gas-hydrate occurrences meet the four gas-hydrate identification qualifiers; therefore, gas hydrates probably do not occur within the wells discussed by Galate and Goodman (1982).

In the Prudhoe Bay-Kuparuk River area all of the well-log inferred gas hydrates occur below the regional Eocene unconformity and within the 450 to $600 \mathrm{~m}$ thick nonmarine to marine sequence overlying the Ugnu interval (figure 4). The gas hydrates occur in six laterally continuous sandstone and conglomerate units and are geographically restricted to the east end of the Kuparuk River Unit and the west end of the Prudhoe Bay Unit (figures 7,8a, and 8b). The gas hydrates occur within relatively porous, discrete rock units. Many wells have multiple gas-hydrate bearing units, with individual occurrences ranging from 3 to 31 meters thick. The boundaries of the gashydrate bearing units in figure $8 \mathrm{~b}$ have been interpolated between well locations at which in-situ gas hydrates have been determined to be either present or absent. Thus, the mapped positions of the gas-hydrate unit boundaries (figure $8 \mathrm{~b}$ ) are open to interpretation. "The six, laterally continuous, discrete gas-hydrate bearing rock units have each been assigned a reference letter (Units A through F), with Unit A being stratigraphically the deepest (table 2; figures 7, 8a, and $8 \mathrm{~b})$. The depth of the identified gas hydrate occurrences are listed in table 2. For 65 of the 138 gas hydrate occurrences noted in table 2 no depths are given for the identified hydrate occurrences; however, the Units that are thought to be gas-hydrate bearing in each well have been noted with the symbol $x$. Data from these 65 potential gas hydrate occurrences were not used due to the lack of confidence in the quality of the available well logs to make accurate depth picks.

Recently completed three-dimensional seismic surveys have documented the occurrence of a gas-hydrate/free-gas contact at the base of the methane-hydrate stability field in the west end of the Prudhoe Bay Oil Field (public presentation, C.G. Guderjahn, British Petroleum Exploration Inc., Anchorage, Alaska). Open-hole logs from wells in the west end of the Prudhoe Bay field also indicate the presence of a large free-gas accumulation trapped stratigraphically downdip below the log inferred gas hydrates (figures $7,8 \mathrm{a}$, and $8 \mathrm{~b}$ ). These well-log delineated free-gas deposits are reservoired within four of the sandstone and conglomerate units that are inferred to contain gas hydrates (Units A, B, C, and D). The presence of a gas-hydrate/free-gas contact within the Westend of the Prudhoe Bay production area is analogous to the Messoyakha gas-hydrate/free-gas accumulation in western Siberia from which $\approx 70$ bcf of gas have been produced from the gas hydrates alone (written communication, Y.F. Makogon, USSR, Academy of Sciences, Moscow; Sloan, 1990). The geologic similarities between these two accumulations suggest that the gas hydrate depressurization production scheme utilized in the Messoyakha field may have direct 


\begin{tabular}{|c|c|c|c|c|c|c|c|c|}
\hline $\begin{array}{l}\text { Map Number } \\
\text { and Well Name }\end{array}$ & $\begin{array}{c}\text { API } \\
\text { Number }\end{array}$ & $\underset{(\mathrm{m})}{\text { Unit } A}$ & $\begin{array}{c}\text { Unit B } \\
(\mathrm{m})\end{array}$ & $\underset{(m)}{\text { Unit } C}$ & $\begin{array}{c}\text { Unit D } \\
(\mathrm{m})\end{array}$ & $\begin{array}{l}\text { Unit E } \\
(\mathrm{m})\end{array}$ & $\begin{array}{l}\text { Unit } F \\
(\mathrm{~m})\end{array}$ & $\begin{array}{l}\text { PF Deptli } \\
\text { (m) }\end{array}$ \\
\hline I Kupuruk State. 1 & 5002920008 & $994-1006$ & 878.895 & $\mathrm{X}$ & $\mathrm{X}$ & & & 516 \\
\hline NW Eileen State-1 & 5002920013 & & & $\mathbf{X}$ & $\mathrm{X}$ & $\mathrm{X}$ & & $\cdot$ \\
\hline W Kuparuk 3.11.: ' & 5002920014 & & & $652-671$ & $600-619$ & 555.573 & & 524 \\
\hline Kavcarak Point $3 i 25$ & 5002920028 & & & $\mathrm{X}$ & $\mathrm{X}$ & $\mathrm{X}$ & & 541 \\
\hline N Kuparuk 26-12-12 & 5002920032 & & & & & $711-725$ & & 630 \\
\hline Becchy Point-1 & 5002920048 & & & $790-798$ & $836-854$ & $\mathrm{X}$ & & $\cdot$ \\
\hline Sucul 33.19E & 5002920060 & & & $\mathrm{X}$ & $\mathrm{X}$ & $547-558$ & & $\cdot$ \\
\hline Kupiaruk 7-11-12 & 5002920062 & & 847.862 & 769.784 & 693.708 & & & 571 \\
\hline 9) Milne Point 18-1 & 5002920069 & & & & & 549.553 & & 512 \\
\hline 10 NW Eileen Si-2 & 5002920117 & & & $639-670$ & $590-598$ & $552-569$ & & 525 \\
\hline II W Sak-2 & 5002920134 & $604-701^{1}$ & & & & & & 481 \\
\hline 12 W Sak-3 & 5002920139 & $318 \cdot 345$ & & & & & & $42 K$ \\
\hline 13 W Sak-5 & 5002920141 & $\begin{array}{l}470-479 \\
487-498\end{array}$ & & & $\cdot$ & & & 42.3 \\
\hline 14 W Sak-6 & 5002920142 & 704.723 & & & & & & $53 !$ \\
\hline 15 Kupuruk $9-11-12$ & 5002920158 & & & $\mathbf{X}$ & & & & 561 \\
\hline 16 Highland St-1 & 5002920199 & $\mathrm{X}$ & $X$ & $695-716$ & $640-646$ & & & 564 \\
\hline 17 KRU ID.8 & 5002920266 & 609.627 & & & & & & 486 \\
\hline I8 MPU A-1 & 5002920376 & & & $608-621$ & $580-599$ & 524.529 & & 510 \\
\hline 19 KRU 1C-1 & 5002920393 & 622.643 & & & & & & 5() 1 \\
\hline 2() Gwydyc Bay St-1 & 5002920396 & & & & & $782-8(x)$ & & 543 \\
\hline $21 \mathrm{KRI} ! \mathrm{ID}-5$ & 5002920417 & $663-690$ & & & & & & 512 \\
\hline 22 Nomination RD-1 & 5002920426 & & 902.905 & $\mathrm{X}$ & $x$ & & & 530 \\
\hline $23 \mathrm{KRU} 1 \mathrm{E}-1$ & 5002920464 & $578-604$ & & & & & & 455 \\
\hline 24 MPU B-1 & 5002920490 & & & $690-693$ & $640-643$ & 579.586 & . & $\cdot$ \\
\hline 25 PBU TR 18-11-12 & 5002920511 & $X$ & 848.866 & & & & & $\cdot$ \\
\hline 26 PBU TR 15.11 .12 & 5002920524 & & & $\mathrm{X}$ & & & & 564 \\
\hline 27 KRU IC.1 & 5002920526 & $X$ & $x$ & $454-528^{2}$ & $421-441$ & $389-398$ & $\begin{array}{l}317-328 \\
339.349 \\
357-366\end{array}$ & 521 \\
\hline $28 \mathrm{KRU} \mathrm{IC}-4$ & 5002920547 & $\mathbf{X}$ & $\mathrm{X}$ & $\mathbf{X}$ & $\mathrm{X}$ & $\mathbf{X}$ & $\mathrm{X}$ & $\cdot$ \\
\hline 2) KRU IC.5 & 5002920550 & $\mathbf{X}$ & $\mathrm{X}$ & $\mathbf{X}$ & $X$ & $\mathbf{X}$ & $\mathrm{X}$ & - \\
\hline 30) KKU IC.6 & 5002920564 & $\mathrm{X}$ & $\mathrm{X}$ & $\mathrm{X}$ & $X$ & $X$ & $\mathrm{x}$ & - \\
\hline 31 Kuparuk 28243-1 & 5002920573 & $\mathrm{X}$ & $X$ & $\mathbf{X}$ & X & & & $\cdot$ \\
\hline $32 \mathrm{KRU} 1 \mathrm{C} .8$ & 5002920585 & $\mathbf{x}$ & $\mathbf{x}$ & $451-520^{2}$ & $419-441$ & 387.397 & $\begin{array}{l}317-334 \\
338-350 \\
356-361\end{array}$ & 5.34 \\
\hline 33 MPU B-2 & 5002920662 & & & $689-695$ & 635.638 & 577.583 & & 478 \\
\hline 34 MPUC-1 & 5002920663 & $X$ & $x$ & X & $\mathrm{X}$ & $\mathrm{X}$ & & 497 \\
\hline 35 MPU D.1 & 5002920664 & & & & $614-621$ & $560-565$ & & 534 \\
\hline 36 W Sak-25 & 5002920719 & & & $504-520$ & 459.473 & $417-424$ & & 536 \\
\hline 37 W Sak-24 & 5002920723 & $760-769$ & $662-676$ & $\mathrm{X}$ & 513.528 & $471-490$ & & 528 \\
\hline 38 KRU $1 \mathrm{H}-6$ & 5002920741 & 579.589 & $\mathrm{X}$ & $\mathbf{X}$ & $371-390$ & 342.354 & & 497 \\
\hline 39) Prudhoc-1 & 5002920796 & & & $\mathbf{x}$ & $\mathrm{X}$ & $\mathrm{X}$ & & $\cdot$ \\
\hline 4() KRU IF.5 & 5002920807 & $\mathrm{X}$ & & & & & & 442 \\
\hline 41 W Sak SWPT-1 & 5002920915 & $\mathrm{X}$ & & & & & & 508 \\
\hline 42 W Sak Pilol 8-I & 5002920994 & $\begin{array}{l}531 \cdot 543 \\
560-577\end{array}$ & & & & & & 427 \\
\hline 43 W End Test. 1 & 5002921033 & & 936.953 & $\mathrm{X}$ & $\mathrm{X}$ & & & 616 \\
\hline 44 W Sak Pilot-5 & 5002921099 & $\begin{array}{l}533-545 \\
562-577\end{array}$ & & & & & & 4.33 \\
\hline 45 W Sak Pilot-7 & 5002921102 & $\begin{array}{l}533-545 \\
562-577\end{array}$ & & & & & & $\cdot$ \\
\hline 46 KRU 2D-15 & 5002921184 & $338-361$ & & & & & & $\cdot$ \\
\hline 47 W Sak-26 & 5002921251 & $\mathrm{X}$ & & & & & & - \\
\hline 48 KRU WT-1 & 5002921526 & $366-387$ & & & & & & - \\
\hline 49 PBU W-40 & 5002921776 & & $X$ & $\mathbf{X}$ & $X$ & & & $\cdot$ \\
\hline $50 \cap B \cup Z .8$ & 5002921787 & & $\mathrm{X}$ & $\mathrm{X}$ & $\mathrm{X}$ & & &. \\
\hline $\begin{array}{l}\text { Thickness Range } \\
\text { Average Thickness }\end{array}$ & & $\begin{array}{l}9.27 \\
16.6 \\
\end{array}$ & $\begin{array}{l}3.18 \\
14.0\end{array}$ & $\begin{array}{l}3.31 \\
14.6\end{array}$ & $\begin{array}{l}3.22 \\
13.4 \\
\end{array}$ & $\begin{array}{l}4.19 \\
10.8\end{array}$ & $\begin{array}{r}30-34 \\
32.0 \\
\end{array}$ & $\begin{array}{l}\text { NA } \\
\text { NA } \\
\end{array}$ \\
\hline
\end{tabular}

${ }^{1}$ Composite of multiple interbedded gas-hydrate-bearing horizons (not used to calculate mean thickness).

${ }^{2}$ Composite of interbedded ice- and gas-hydrate-bearing horizons (not used to calculate mean thickness).

Table 2. North Slope wells with inferred gas hydrate occurrences. The depth of 73 well $\log$ inferred gas hydrate occurrences have been listed along with the depth of the base of the icebearing permafrost in 34 wells (measured from mean-sea-level). The map location of the wells are shown in figure 8. An additional 65 potential gas hydrate occurrences have been denoted with an (x), and wells with unknown ice-bearing permafrost depths have been denoted with a (-) in the last column. 


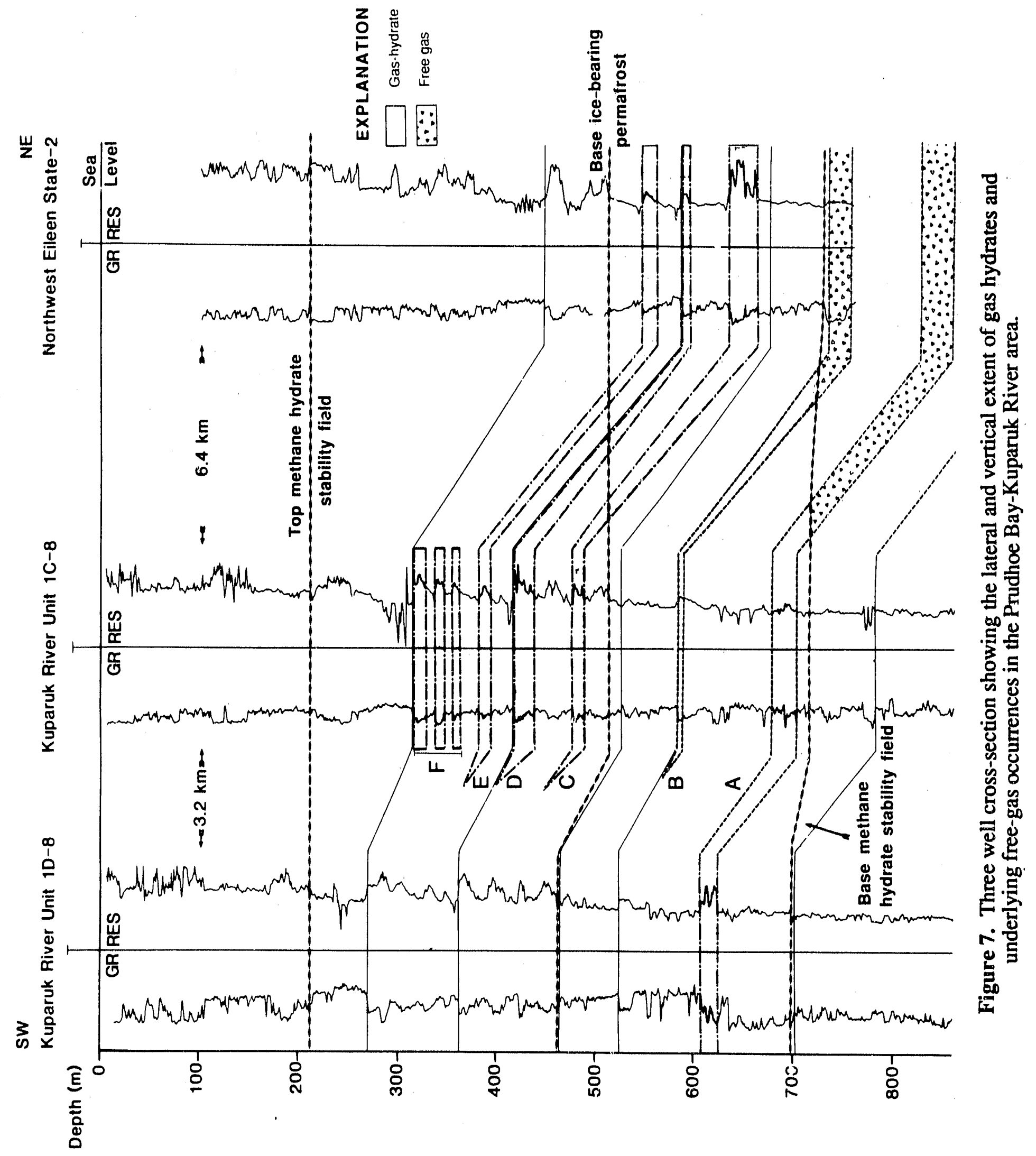



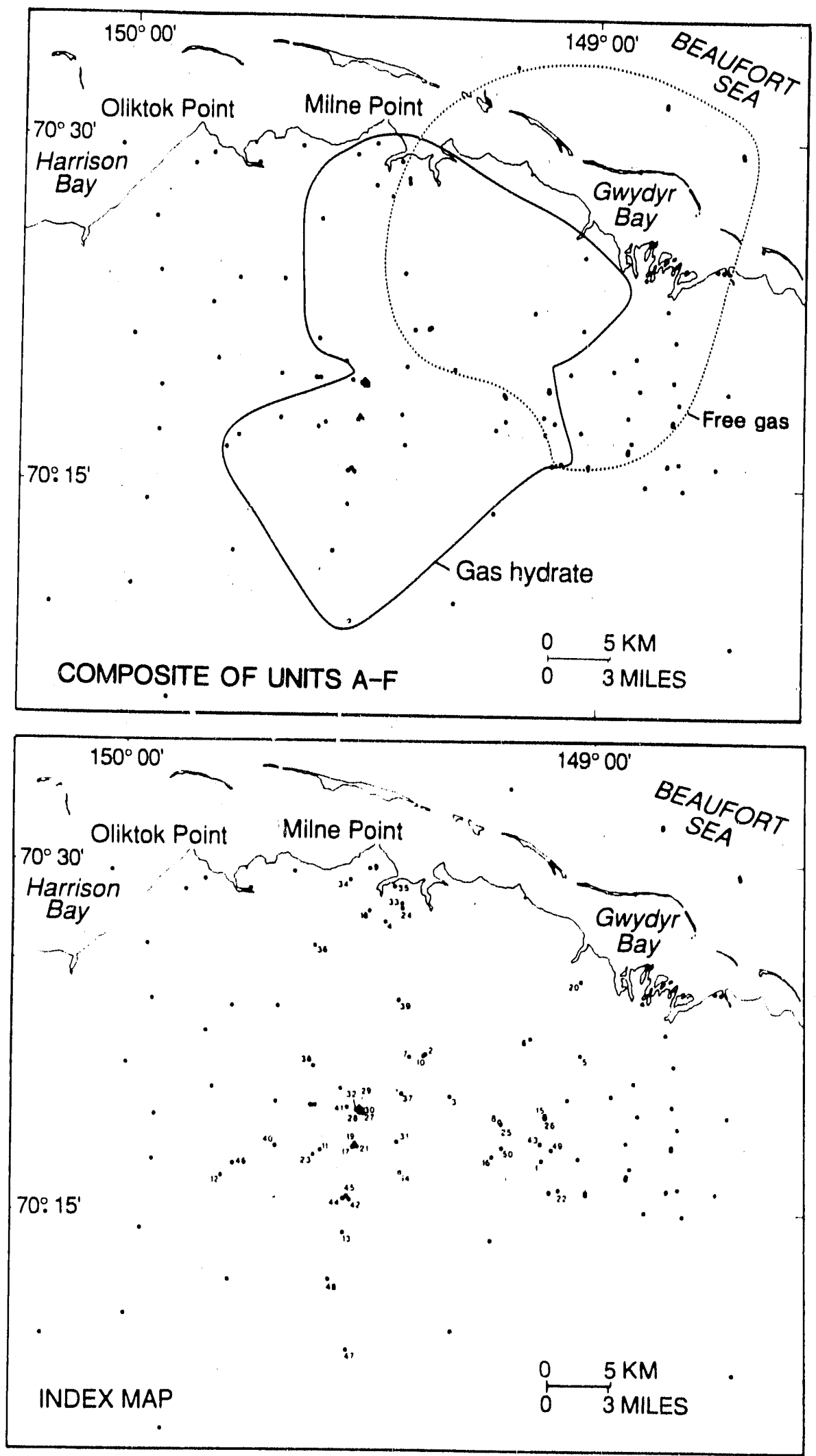

Figure 8a. Composite map of all six gas-hydrate/free-gas Units (A-F) from the Prudhoe BayKuparuk River area. The index map depicts the 50 wells inferred to contain gas hydrates (see table 2 for well names). 

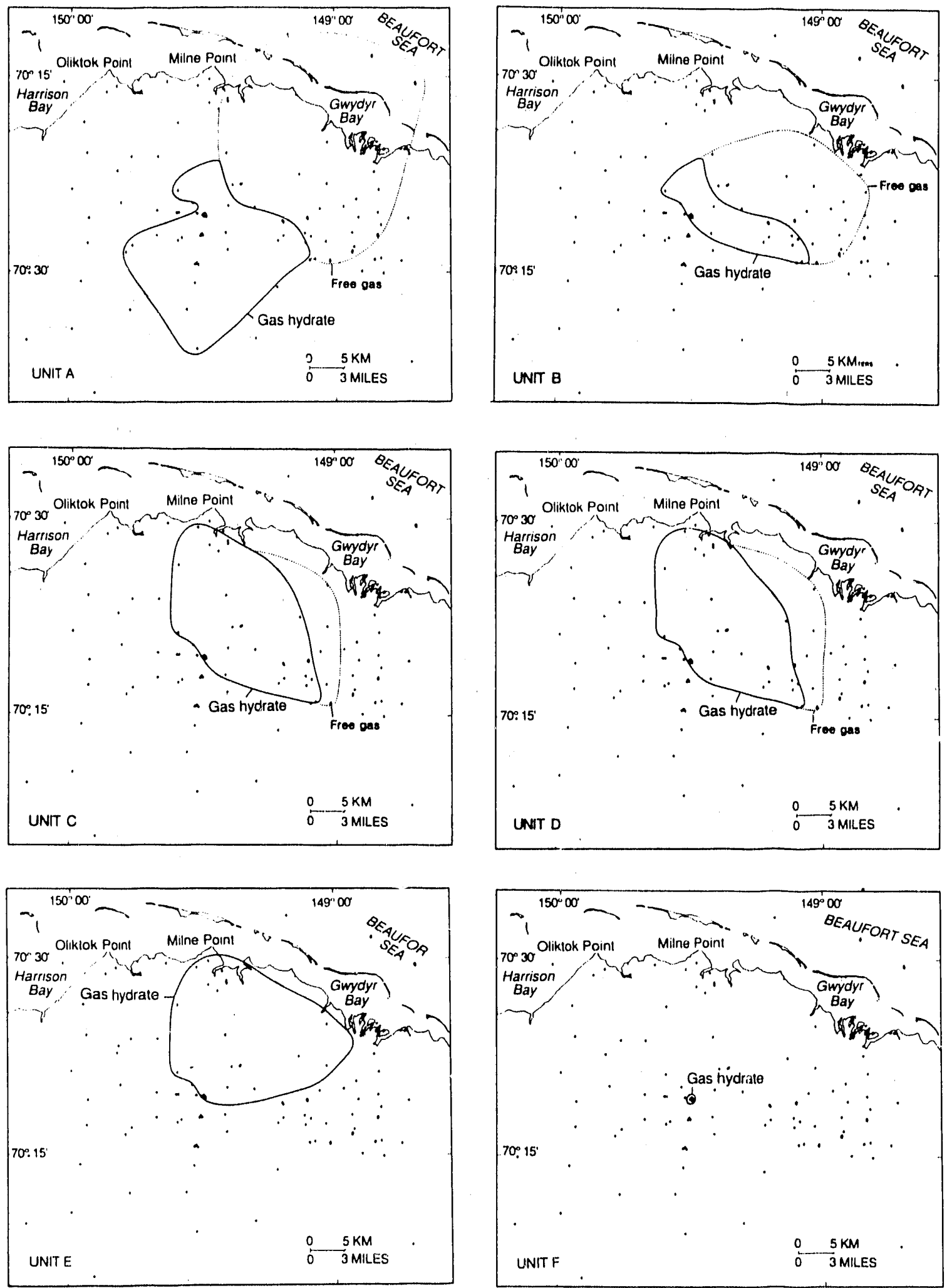

Figure 8b. Maps depicting the geographic distribution of each (Units A-F) well-log inferred gas hydrate occurrence in the Prudhoe Bay-Kuparuk River area. 
application in northern Alaska. For more information on gas hydrate production methods see Yousif and others (1988), and Sloan (1990). Depicted together in figures 8a and $8 \mathrm{~b}$ are the geographic distribution of the well-log inferred gas hydrates and underlying free-gas occurrences.

Examination of the maps in figure $8 \mathrm{~b}$ shows that Unit $\mathrm{A}$ is gas-hydrate bearing throughout the southeastern portion of the Kuparuk River Oil Field. The total area in which Unit A is gashydrate bearing is approximately $394 \mathrm{~km}^{2}$. The thickness of the gas hydrate deposit in Unit A ranges from 9 to $27 \mathrm{~m}$, with an average thickness of $16.6 \mathrm{~m}$. Also reservoired in the gas-hydratebearing portion of Unit $A$ is a significant volume of oil, both in the Kuparuk River and Prudhoe Bay fields. Most of the gas hydrates in Unit A occur below the base of ice-bearing permafrost. In addition, mud $\log$ data suggest that the up-dip portion of Unit $A$ in the Kuraruk River development area is gas-hydrate bearing above the base of ice-bearing permafrost. Reservoired belcw that base of the gas hydrate stability field in Unit A is a significant volume of free-gas and oil (figure 8b). Well log and drill-cuttings analyses have also revealed the presence of several thick coal seams within Unit A. The gas hydrates of Unit B have a total areal distribution of approximately 122 $\mathrm{km}^{2}$ and thickness ranging from 3 to $18 \mathrm{~m}$. Coal is also abundant in Unit B; there is also evidence of reservoired free-gas below the base of the gas hydrate stability field in Unit B. All the gas hydrates in Unit B occur helow the base of ice-bearing permafrost. The gas hydrates of Units C and $D$ are both laterally extensive and exhibit similar reservoir rock properties. The gas hydrates of Unit $C$ have a total areal distribution of approximately $363 \mathrm{~km}^{2}$, and the total lateral extent of the gas hydrates in Unit $D$ is approximately $357 \mathrm{~km}^{2}$. Unit $C$ is the cored gas-hydrate sequence in the Northwest Eileen State-2 well. The southern- and western-most gas hydrates in Units C and D occur within the ice-bearing permafrost sequence (table 2), with several occurrences more than 200 $\mathrm{m}$ above the base of ice-bearing permafrost. Down-dip, below the gas hydrate stability field, both Units $C$ and $D$ contain a relative small volume of free-gas. Unit $E$ is shown to be gas-hydrate bearing over a large area in the northern part of the study area (figure $8 \mathrm{~b}$ ). The total areal

distribution of the gas hydrates in Unit $\mathrm{E}$ is approximately $404 \mathrm{~km}^{2}$. Gas hydrates of Unit $\mathrm{E}$ also appear to transect the base of ice-bearing permafrost with the farthest southwestern up-dip extension of the gas hydrates more then $14 \hat{\mathrm{c}} \mathrm{m}$ above the base of ice-bearing permafrost. Their is no evidence of free-gas trapped below the hydrates in Unit E. Gas hydrates of Unit F are a composite of three gas-hydrate bearing rock units drilled in several wells from the Kuparuk River Unit 1C production pad (figure $8 \mathrm{~b}$ ). These hydrate occurrences were first recognized during drilling when a significant volume of gas leaked from around the outside of the casing into the basement of the drilling rig (data from State of Alaska Oil and Gas Conservation Commission well files). The combined total thickness of these units range from 30 to $34 \mathrm{~m}$, and the total surface area of these occurrences is approximately $3 \mathrm{~km}^{2}$.

It is assumed that the gas-hydrate deposits depicted in figures $8 \mathrm{a}$ and $8 \mathrm{~b}$ are laterally continuous. However, because of the scarcity and the poor quality of the well logs, the lateral extent of the gas hydraces cannot be established with certainty. The stuty of gas hydrate samples recovered during research coring operations in the Pacific Ocean suggest th:at the physical nature of in-situ gas hydrates are highly variable (Kvenvolden and McMenamin, 1980). Gas hydrates were observed to be either: (1) occupying pores of coarse-grained rocks; (2) disseminated nodules within fine-grained rocks; (3) as a solid, filling frac'ures; or (4) as a massive unit composed mainly of solid hydrate with minor amounts of sediment. Because of the lack of hydrate samples, it is not known if the North Slope hydrates are pore-filling material or occur as massive units. It is apparent that new data are requirea to determine accurately the lateral extent and physical nature of the hydrate occurrences on the North Slope.

\section{GAS-HYDRATE RESERVOIR PROPERTIES}

Two of the most difficult gas-hydrate reservoir properties to determine accurately are reservoir porosity and the degree of gas-hydrate saturation. The primary reason for this difficulty is the lack of previous field and laboratory studies. Well logs often serve as a source of porosity 
data; however, the determination of porosity with well logs in gas-hydrate or ice-bearing horizons is subject to error. This work shows that calculations from the acoustic log in a gas-hydrate unit can underestimate porosities from 16 to 20 percent. Porosity within a gas-hydrate bearing reservoir is most reliably derived with a borehole-compensated neutron device which will be in error by only 3\% (Collett and others, 1984). To determine the porosities of the North Slope gashydrate reservoir rocks, 71 neutron-porosity calculations were made within the identified gas hydrates in seven of the wells studied. These porosity values, which range from 22 to 48 percent, are plotted in figure 9. Because of significant scatter in the calculated neutron porosities, the suspected neutron porosity error of $3 \%$ is negligible. An average trend-line, fitted to the calculated porosities, (figure 9) shows a $1 \%$ decrease per $100 \mathrm{~m}$. Also shown are core-derived porosity trend-lines for rocks in this area. Howitt (1971) reported measured porosities raging from 40 to 45 percent within the permafrost sequence $(0-610 \mathrm{~m})$ of the Prudhoe Bay area, and Werner (1987) showed that the West Sak sands have porosities ranging from 25 to 35 piscent below the permafrost sequence $(1,000-1,300 \mathrm{~m})$ in the Kuparuk River area. The core- and log-calculated porosity trends show remarkably close agreement (figure 9). Presumably, the porosity reduction with depth is caused exclusively by compaction. A best-fit porosity trend-line was projected through the core- and log-derived porosities (figure 9 ). This porosity curve (1\% porosity decrease per $100 \mathrm{~m}$ ) was used to calculate the average porosity of the gas-hydrate reservoirs. These calculations were made by comparing the depth interval of each gas-hydrate occurrence with the porosity trend-line in figure 9 (table 3 ).

It is assumed that a Pickett crossplot, which is commonly used to determine oil-saturations in oil/water systems, can be applied to determine the degree of gas-hydrate saturation in a gashydrate- and water-bearing rock unit (Collett and others, 1984; 1988). No laboratory or core studies have been conducted to test the usefulness of the Pickett crossplots relative to gas-hydrate research; thus, the accuracy of this procedure is not known. A series of Pickett crossplots were used to calculate gas hydrate saturation in four of the six delineated gas-hydrate occurrences (Units $B, C, D$, and E). This crossplot procedure for determining gas-hydrate saturation is not valid when ice or other hydrocarbons are present. Therefore, only sub-permafrost, non-oil-bearing gas hydrates were considered. Because Unit A is oil-bearing and all of Unit $F$ is within the permafrost sequence, these units have been omitted from the saturation calculations. In the composite Pickett crossplot in figure 10 the corrected neutron-porosity and deep-resistivity log values have been plotted for twenty-seven gas-hydrate occurrences. Of the twenty-seven gas-hydrate occurrences depicted in figure 10 , six are from Unit $B$, seven from Unit $C$, nine from Unit $D$, and six from Unit $E$. In figure 10 , the formation water resistivity line was constructed with a $R_{W}$ value of 0.4 ohm-m (pore-fluid salinity $\approx 10$ to $\approx 15 \mathrm{ppt}$ ). The crossplot in figure 10 shows that gas-hydrate saturation in Units $B, C, D$, and $E$ range from 70 to 95 percent and generally average about $85 \%$ (table 3).

\section{POTENTIAL GAS-HYDRATE TRAPS}

In the gas-hydrate reservoir rocks of the Prudhoe Bay-Kuparuk River area, little is known about potential hydrocarbon traps. For instance, it is not known if the faults within the West Sak and Ugnu sands (Werner, 1987) extend into overlying horizons. Most of the sediments that comprise the gas hydrate reservoir rocks were deposited in a delta plain environment in which stratigraphic traps are common. Therefore, it is possible that lateral facies changes may provide hydrocarbon traps within these horizons; however, due to the unconsolidated nature of these rocks the efficiency of a seal may be reduced.

Two additional trapping mechanisms not previously discussed are relatively specialized. Permafrost (ice-bearing permafrost) is believed to be an effective impermeable barrier to migrating gas and liquids (Downey, 1984). Therefore, the base of ice-bearing permafrost could act as a hydrocarbon seal, but ice-bearing permafrost is not believed to be a present-day trap for the West Sak or Ugnu oils (Werner, 1987). Ice-bearing permafrost hydrocarbon traps may exist, however, 


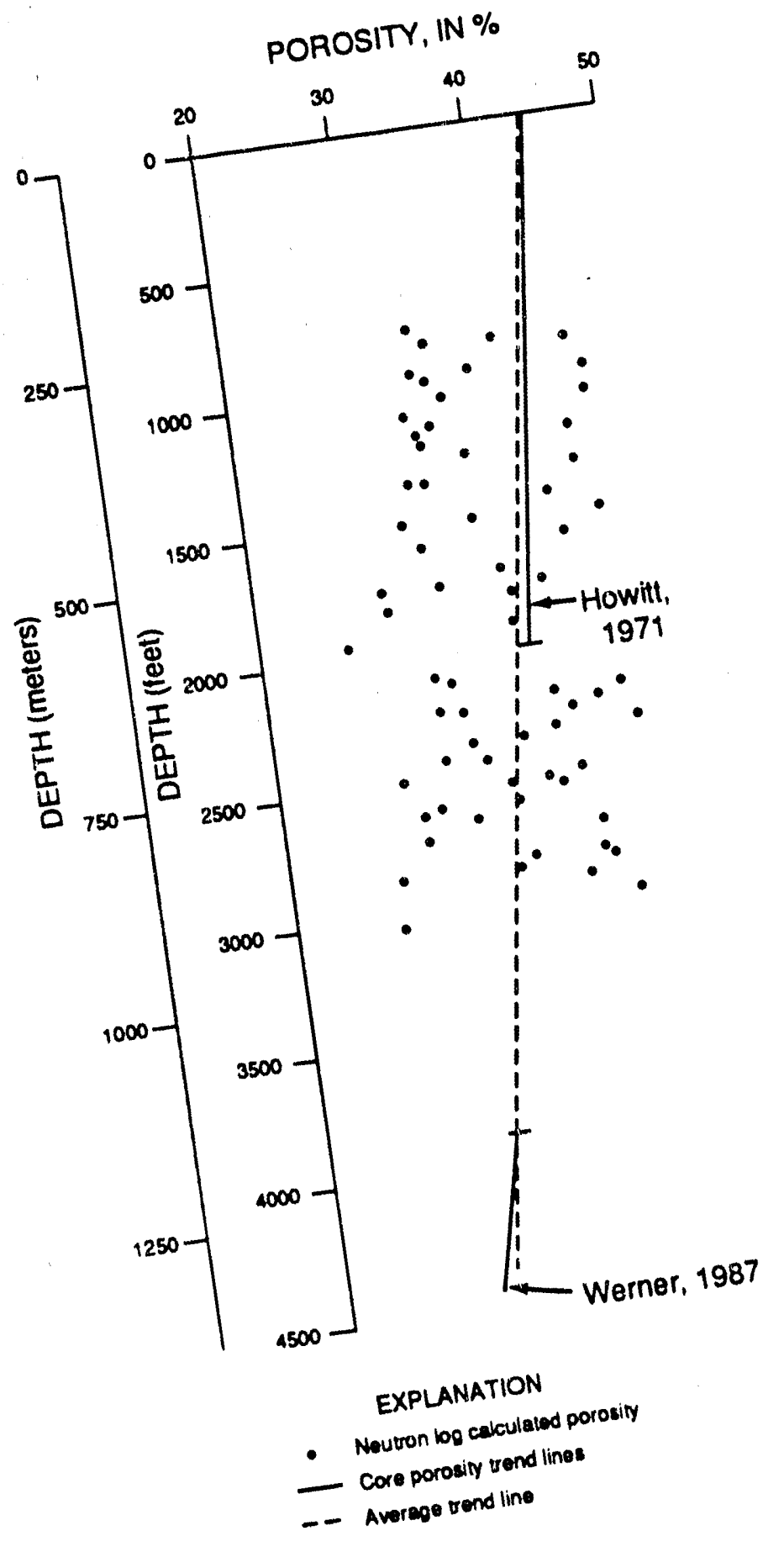

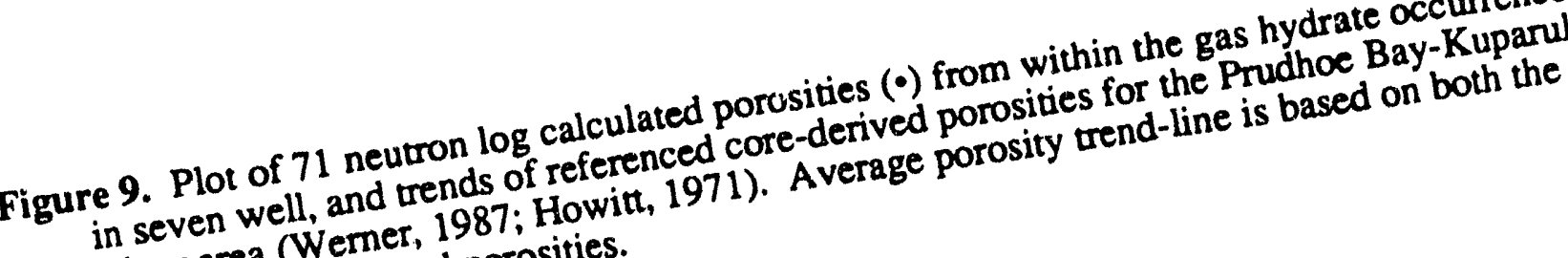

River area (Wemerved porosities.

log 


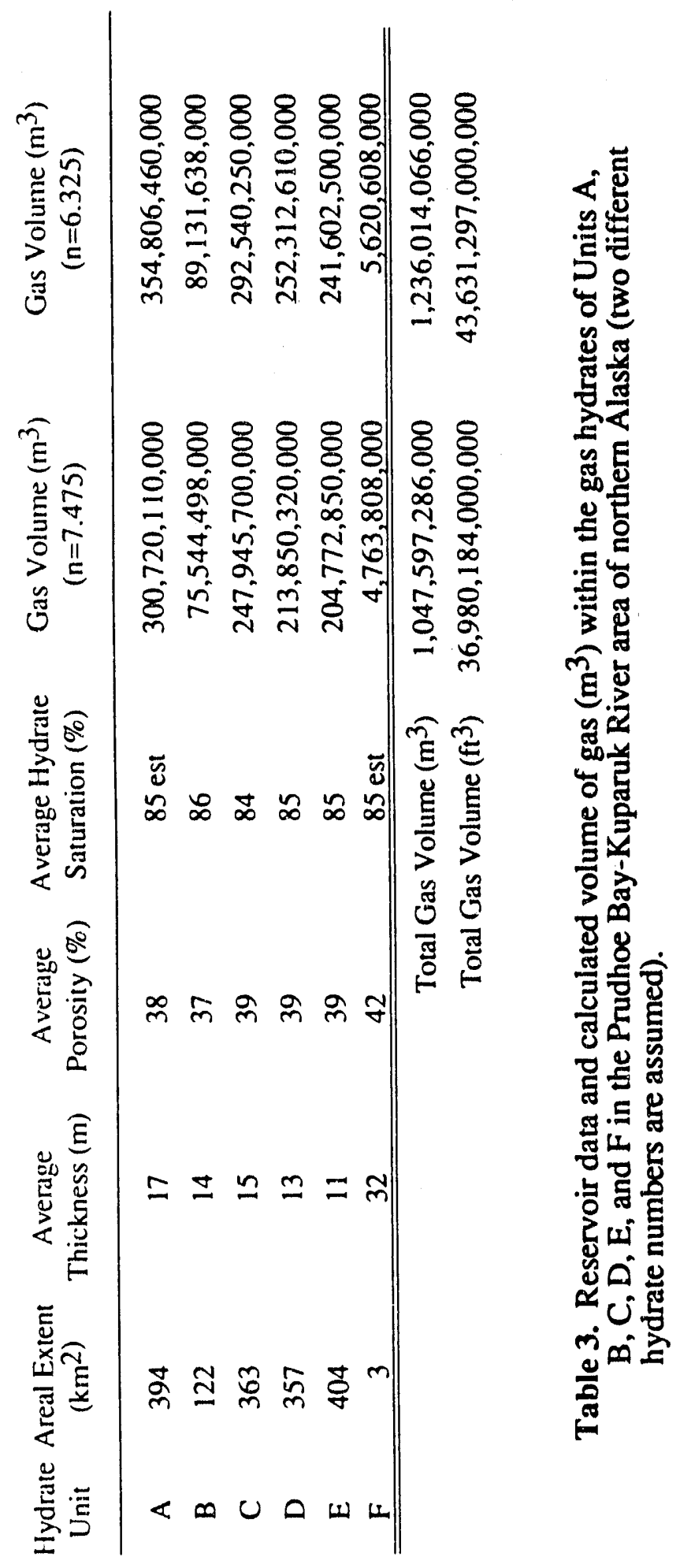




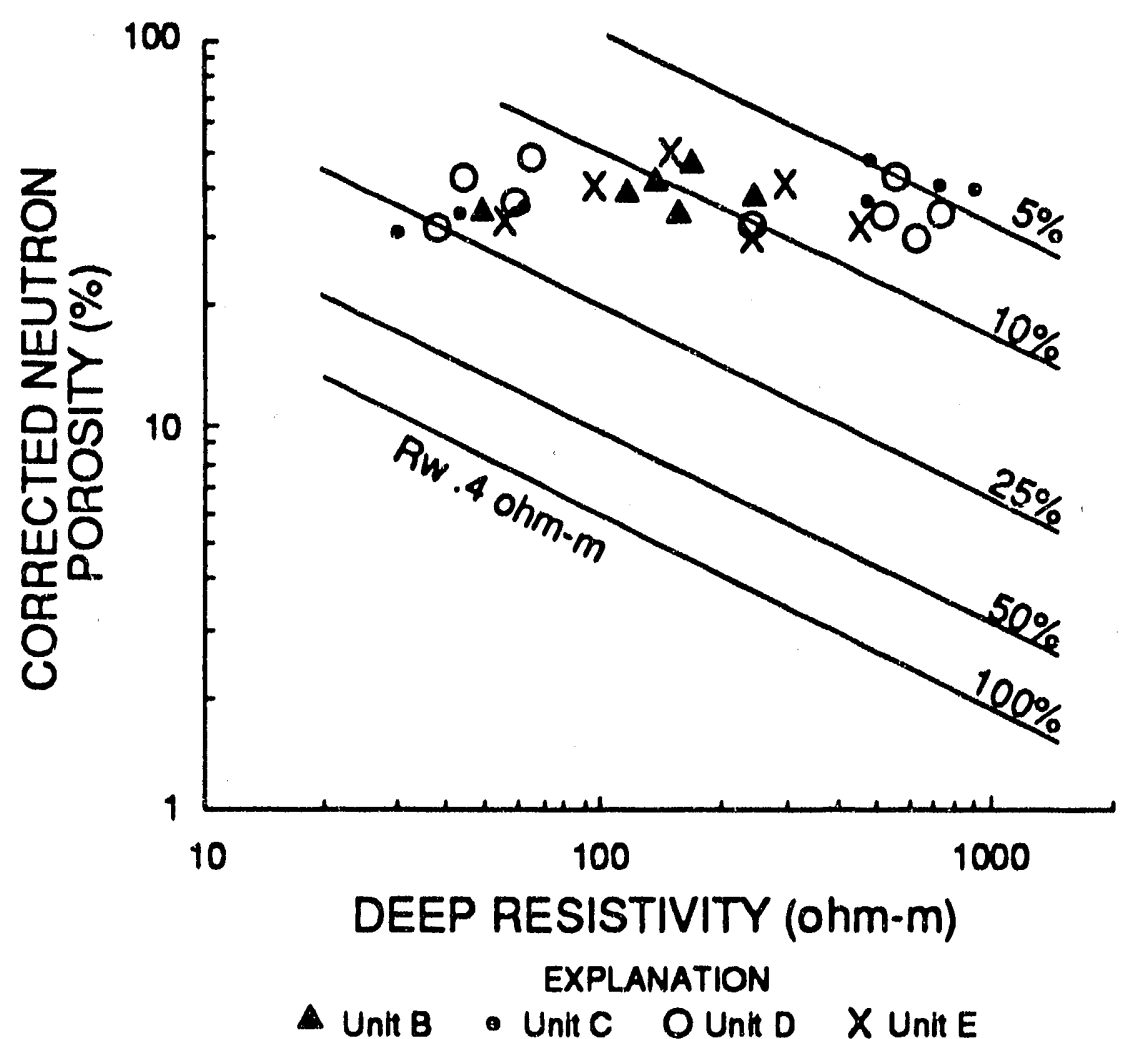

Figure 10. Composite Pickett cross plot used to calculate gas-hydrate saturation in (gas hydrate) Units B, C, D, and E (the \% saturations depicted on the plot is the \% of water saturation). 
within the reservoir rocks overlying the Ugnu sands. In addition to the permafrost hydrocarbon traps, it is possible for gas hydrate to form its own trap in a reservoir. As gas migrates into the zone of gas-hydrate stability, it may interact with the available pore-water to generate gas hydrate. With the appropriate volumes of gas and water, the pore-space within the reservoir rock could be completely filled, thus making the rock impermeable to further hydrocarbon migration. The plugging of gas pipelines and production tubing by gas hydrates is an example of its sealing porential (Hammerschmidt, 1934).

\section{GAS-HYDRATE RESOURCE ESTIMATE}

Previous estimates of the gas volurie that may be attributed to gas hydrates on the North Slope range from $3.1 \times 10^{11}$ to $7,100.0 \times 10^{11} \mathrm{~m}^{3}$ (approximately 11 to 25,000 tc f of gas) (Potential Gas Agency, 1981). The broad range of these estimates demonstrates a general lack of knowledge pertaining to actual gas-hydrate occurrence and distribution; ho'vever, estimates of this magnitude are of interest especially when compared with the identified North America resource of conventional natural gas of only $142 \times 10^{11} \mathrm{~m}^{3}$ (approximately $503 \mathrm{tcf}$ of gas) (Masters and others, 1987).

Most of the published estimates of gas volumes from hydrates have of necessity been made by broad extrapolation of only general knowledge of local geologic conditions that control the distribution and volume of in-situ gas hydrates. Gas volumes that may be attributed to gas hydrates in a permafrost setting are dependent on five reservoir properties: (1) areal extent of the gas-hydrate occurrences, (2) reservoir thickness, (3) porosity, (4) hydrate number, and (5) the degree of gas-hydrate saturation. In the following section each of these parameters are riviewed for the North Slope and a gas (hydrate) resource estimate is made.

As previously discussed, all identified gas hydrates on the North Slope occur in the Prudhoe Bay-Kuparuk River area, in six delineated gas-hydrate units (Units A through F; figure $8 b)$. The total mapped area of all six gas-hydrate occurrences is about $1,643 \mathrm{~km}^{2}$, with the areal extent of the individual units ranging from 3 to $404 \mathrm{~km}^{2}$ (table 3 ). The thickness of the gashydrate occurrences in Units A through F (table 2) are highly variable. The thickest gas-hydrate occurrences are those of Unit A, with an average thickness of $\approx 17 \mathrm{~m}$. The thinnest gas-hydrate sequence is that of Unit $E$, with an average thickness of $\approx 11 \mathrm{~m}$. In this resource estimate, only average values of thickness are used (table 3). The average porosity of each gas-hydrate reservoir, previously calculated, are listed in table 3. As shown in table 3 the calculated porosities of the gashydrate reservoir rocks range from 37 to $42 \%$, and average approximately $39 \%$ (table 3 ).

The hydrate number can be visualized as a factor describing how much of the clathratecage-structure is filled with gas. If the clathrate structure of a methane hydrate is completely filled, the gas hydrate would have a hydrate number of 5.8 (Holder and Hand, 1982). However, it is believed that a $100 \%$ gas-filled clathrate is not likely to be found in nature. On the other hand, gas hydrates are not stable if the clathrate cages are less then $70 \%$ occupied by gas. For the purpose of this study, the gas-hydrate volume calculations were conducted assuming two conditions; the clathrate is $90 \%$ filled (hydrate number 6.325 ) or the clathrate is $70 \%$ filled (hydrate number 7.475) (Holder and Hand, 1982). This range in the hydrate number will fully represent the likely minimum and maximum values that occur in nature. It is known from the work of Holder and Hand (1982), that one cubic meter of methane hydrate with a hydrate nu ber of 6.325 yields 164 cubic meters of methane (at STP), and a cubic meter of methane hydrate with a hydrate number of 7.475 yields 139 cubic meters of methane (at STP). These gas hydrate yield factors have been used to determine the total volume of gas that may be contained within the hydrates.

The last variable required for a resource estimate is gas-hydrate saturation. It is speculated that the well-log calculation of gas-hydrate saturations is similar to calculating more common hydrocarbon saturations, as previously discussed. The average degree of gas-hydrate saturation within each hydrate reservoir (Units A through F) are listed in table 3. 
For each gas-hydrate bearing reservoir, we have calculated the areal extent, average stratigraphic thickness, average porosity, total volume of reservoir porosity, and the a verage degree of gas-hydrate saturation (table 3 ). The theoretical minimum $(n=6.325)$ and maximum ( $n$ $=7.475$ ) hydrate numbers have been used to estimate the volume of gas that may be attributed to the identified gas hydrates (table 3). These calculations indicate that the potential volume of gas within the identified gas hydrates of the North Slope is approximately $1.0 \times 10^{12}$ to $1.2 \times 10^{12} \mathrm{~m}^{3}$ (at STP) [approximately 37 to 44 tcf of gas]. The volume of gas estimated to be present as gas hydrates is about twice the amount of recoverable natural gas (estimated at approximately $8.0 \mathrm{x}$ $10^{11} \mathrm{~m}^{3}$ ) in the Prudhoe Bay field (State of Alaska Oil and Gas Conservation Commission).

Our North Slope gas-hydrate resource estimate must be considered to be relatively conservative because most of the North Slope is sparsely drilled. Outside of the Prudhoe Bay and Kuparuk River development units, drilling density is less than one well for every $500 \mathrm{~km}^{2}$. Our resource evaluation considers only the well-log delineated gas hydrates which cover an area of only $\approx 400 \mathrm{~km}^{2}$. Regional geologic information and seismic data suggest that large areas of the North Slope are underlain by relatively good reservoir rocks within the zone of gas-hydrate stability. Because of the low well density of this region, this resource estimate should be considered a minirnum value.

\section{GEOLOGIC HISTORY OF GAS HYDRATES}

Relatively little is known about the history of gas-hydrate formation on the North Slope. However, recent geologic and geochemical studies from the Prudhoe Bay-Kuparuk River area have provided ne $N$ insight into the geologic parameters controlling the distribution of gas hydrates.

In developing a model for the origin of gas hydrates on the North Slope, the following observations pertaining to the distribution and geochemical makeup of the gas hydrates must be accounted for: (1) All the gas hydrates found to date are near the eastern boundary of the Kuparuk River oil field and extend into the west end of the Prudhoe Bay oil field, an area cut by faults extending deep into the stratigraphic section; (2) gas hydrates are present in a series of sandstone units that dip gently to the northeast; (3) all the gas hydrates are below a relatively impermeable marine siltstone sequence; (4) oil and tar are found within one inferred gas-hydrate-bearing interval; (5) the gas hydrates are likely composed of methane gas derived from both microbial and thermogenic sources.

\section{Source of the Gas Within the Gas Hydrates}

Carman and Hardwick (1983) postulated that oil within the West Sak and Ugnu sands migrated along faults from the underlying Prudhoe Bay oil field. If this hypothesis is correct, freegas from within the Sadlerochit reservoir and dissolved gas associated with oils would also have migrated into the overlying sedimentary rocks. As shown in figure 11, most of the gas hydrates and shallow heavy oils occur either up-dip from or near the Eileen fau', zone. This fault zone may have acted as a conduit for free-gas and oil migration from deeper hydrocarbon accumulations. Geochemical analysis of drill-cuttings collected from seven industry development wells drilled in the Prudhoe Bay and Kuparuk River oil fields have been used to characterize the composition and source of the hydrocarbon gas within the interval of gas-hydrate stability (Collett and others, 1990). These analysis suggest that methane is the principal hydrocarbon gas in the near-surface $(0-1,500 \mathrm{n})$ s.rata of the North Slope. Stable methane carbon isotopic analyses of gaseous drillcuttings from several gas-hydrate-bearing rock units yielded carbon isotopic values averaging approximately -49 permil, thus, suggesting that the methane within the inferred gas-hydrate occurrences is from ixed sources, microbial and thermogenic. Gas with stable carbon isotopic compositions -50 permil and heavier are considered to be thermally generated; conversely, an isotopic composition of -60 permil or lighter indicates that the gas was formed by microbial 


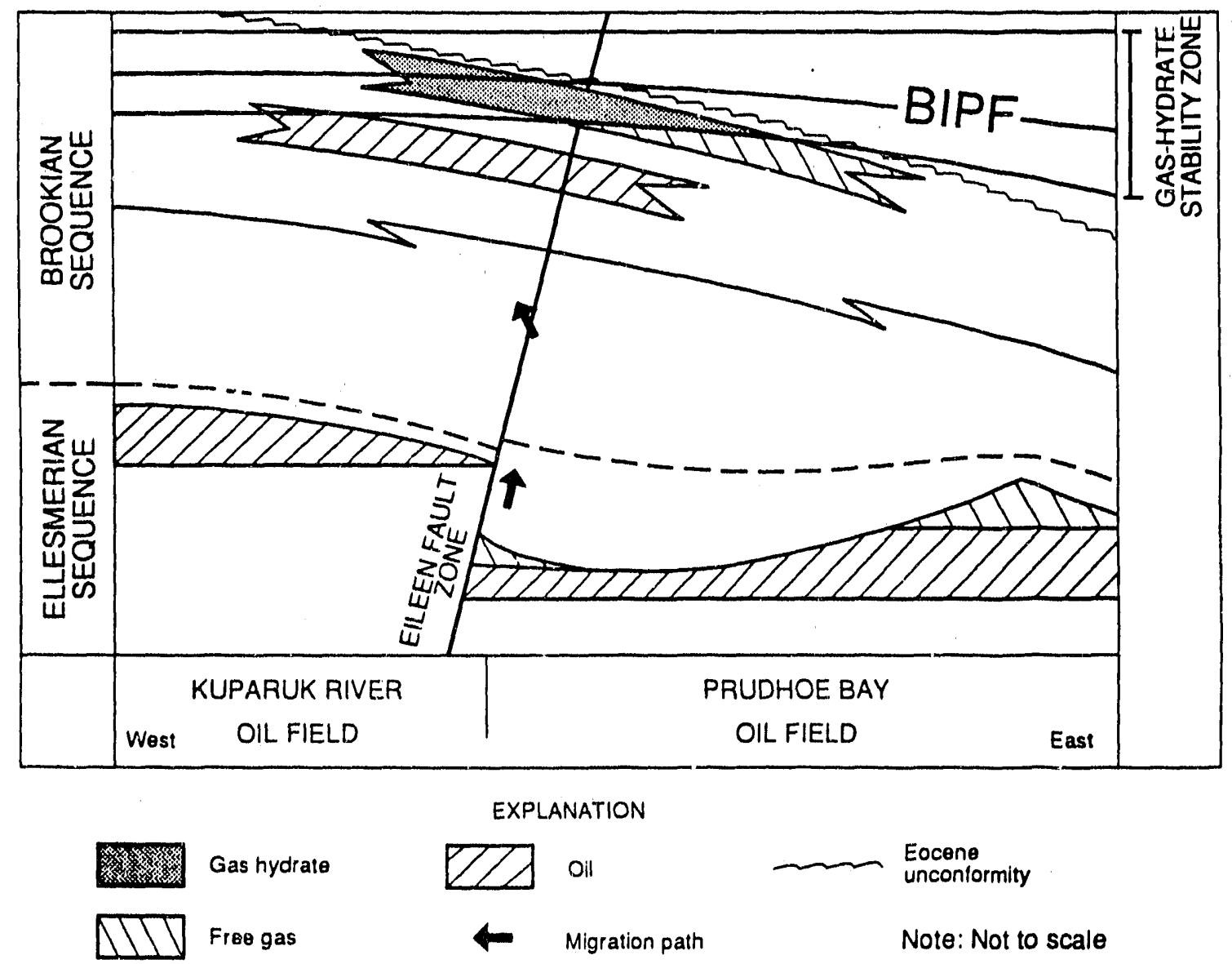

Figure 11. Schematic west to east cross section through Prudhoe Bay-Kuparuk River area illustrating possible gas migration paths and spatial relations between gas hydrates, free-gas, oil, Eileen fault zone, base of ice-bearing permafrost (BIPF), and gas-hydrate stability field (adapted from Carman and Hardwick, 1983, figure 13). 
processes. Vitrinite reflectance $\left(R_{0}\right)$ measuremeuts of about 0.4 percent show that the gas-hydratebearing rocks have never been subjected to temperatures within the thermogenic window. Thus, the thermogenic gas must have migrated from greater depths.

The gas cap of the Prudhoe Bay field is composed primarily of methane ( 83 to $88 \%$ ) along with small quantities of ethane (5 to $7 \%$ ) and propane (1 to $2 \%$ ) (written communication, M.C. Davidson, BP Exploration, Anchorage, Alaska). If the gas within the near-surface sediments migrated from deeper structures, these shallow gases should have geochemical constituents similar to those of the deeper gases. However, no significant amounts of ethane or propane were detected within the interval of gas-hydrate stability. The depletion of heavier hydrocarbons such as ethane and propane from gas mixtures by stripping during migration has been suggested by Schoell (1983) and Jenden and Kaplan (1986) to explain natural gases containing thermogenic methane but only minor amounts of heavier hydrocarbons. The thermogenic component of the gas within the interval of gas-hydrate stability of the North Slope may have been stripped of most of its heavier hydrocarbons. Such a process could account for the molecular and isotopic compositions observed.

As noted, a -49 permil stable methane carbon isotopic composition suggest that the gas hydrates contain a mixture of thermogenic and microbially sourced gas. By comparing the methane carbon isotopic composition of this apparent gas mixture to the isotopic composition of the Prudhoe Bay gas cap it is possible to calculate the relative volume of thermogenic verses microbially sourced gas within the hydrate stability field. The methane carbon isotopic analysis of the Prudhoe Bay gas cap, considered to be a source for some of the gas within the hydrates, yield an average value of approximately -39 permil (written communication, M.C. Davidson, BP Exploration, Anchorage, Alaska). The microbially sourced methane component likely had an original methane isotopic composition ranging from -60 to -70 permil. Because the mixing of two gases results in a linear and proportional change in isotopic composition (Schoell, 1983), it is estimated that about 50 to 70 percent of the methane within the hydrate stability field has migrated from the Prudhoe Bay gas cap. The presence of oil within one of the gas-hydrate-bearing units supports the theory that oil and gas must have migrated from the underlying Prudhoe Bay oil field.

An additional observation which strengthens the idea that migrating gas was involved with gas-hydrate formation is that all of the gas hydrates occur regionally below a 50 to $80 \mathrm{~m}$ thick marine siltstone sequence (figures 4 and 7 ). This relatively impermeable rock sequence may act as a barrier to vertical gas migration, thus controlling the distribution of gas hydrate. Such a barrier may explain why no gas hydrates are present in the eastern part of the Prudhoe Bay oil field. Because of the regional northeastward dip, all potential gas-hydrate-bearing rock units in eastern Prudhoe Bay occur below the zone of gas-hydrate stability. Thus, a limited supply of gas to the zone of gas-hydrate stability prevents hydrate formation.

\section{Origin and Timing of Gas Hydrate Formation}

To describe the history of gas-hydrate formation, we have adapted a generalized cross section (figure 11) from Carman and Hardwick (1983; fig. 4). As gas moved up the Eileen fault zone and encountered relatively porous and permeable northeast-dipping sandstone units, some of the gas may have been rechanneled up-dip along these beds. The up-dip migrating gas may have collected in structural or stratigraphic traps where subsequent temperature changes deepened the permafrost sequence and converted the trapped gas into gas hydrate. Conversely, the up-dip migrating gas may have converted to gas hydrate upon entering the pressure-temperature regime of gas-hydrate stability, thus forming its own trap. Because so little is known about the history of temperatures on the North Slope and the presence of traps for free-gas in this area, either of these scenarios is plausible. However, I speculate that gas hydrates presently occur more than $160 \mathrm{~m}$ above the base of ice-bearing permafrost, which is assumed to be impermeable (Jamison and others, 1980; Downey, 1984). Therefore, when gas migrated into these upper horizons, the base of the ice-bearing permafrost must have been at least $160 \mathrm{~m}$ shallower than today. 
Since the onset of gas migration into these near-surface horizons (middle Tertiary time), temperatures have fluctuated significantly. It is generally believed that thermal conditions conducive to the formation of permafrost and gas hydrates have persisted in northern Alaska since the end of the Pliocene ( $\approx 2.4$ m.y.b.p.); however, regional temperature fluctuations throughout the Pleistocene ( $\approx 1.7$ to 0.01 m.y.b.p.) have been great enough to repeatedly thicken and thin permafrost and the zone of gas-hydrate stability (Carter and others, 1986; Lachenbruch and others, 1982). The magnitude and duration of these temperature changes are not well documented. It is also known that a surface water body of depth sufficient to prevent complete freezing inhibits or prevents the formation of permafrost (Lachenbruch, 1957) and gas hydrates. Therefore, the paleopositions of the Arctic Ocean coastline is important in understanding the history of gas hydrates. Lachenbruch and others (1982), have demonstrated that surfacial thermal disturbances take many thousands of years to alter deep subsurface temperatures in ice-bearing rock sequences. For example, if the Prudhoe Bay area was rapidly submerged under the Arctic Ocean, the base of permafrost will rise about $10 \mathrm{~m}$ (from a depth of $\approx 600 \mathrm{~m}$ ) during the first 2,000 years, and there after it would rise about $15 \mathrm{~m}$ per every 1,000 years; thus after 20,000 years the depth of permafrost would still be over $300 \mathrm{~m}$ (Lachenbruch and others, 1982) and part of the gas-hydrate stability field will still exist. Therefore, when examining the history of gas hydrate formation on the North Slope, all atmospheric temperature changes and marine transgressive/regressive events that persisted for more then approximately 20,000 to 30,000 years must be considered significant. As of this time we don't have an adequate appreciation of climatic and geologic changes on the time scale necessary to completely assess the history of gas hydrate formation in northern Alaska. Certainly more work is needed to establish the history of subsurface temperatures on the North Slope.

\section{CONCLUSION}

On the North Slope of Alaska gas hydrates occur in a series of discrete rock units overlying the eastern part of the Kuparuk River Oil Field and the western part of the Prudhoe Bay Oil Field. The volume of gas within these hydrates is approximately $1.0 \times 10^{12}$ to $1.2 \times 10^{12}$ cubic meters (37 to 44 trillion cubic feet). Two possible explanations for the origin of the gas hydrates in the Prudhoe Bay-Kuparuk River area are recognized. (1) Thermogenic solution gas and free-gas from reservoirs of the Prudhoe Bay oil field migrated upward along the Eileen and other fault zones into the overlying shallow sedimentary rocks. In these rocks, in-situ microbial gas mixed with the thermogenic gas, causing total gas concentrations to reach amounts that triggered gas-hydrate formation within the zone of gas-hydrate stability. (2) Concentration of in-situ and migrated gas in shallow traps which initially were outside the zone of gas-hydrate stability, but moved into that zone in response, for example, to climate cooling over the last 2.4 million years; thus, causing gas hydrates to form both within and beneath permafrost.

\section{REFERENCES CITED}

Anderson, D.M., Tice, A.R., and McKim, H.L., 1973, The unfrozen water and the specific heat capacity of frozen soils, in Proceedings of the Second International Conference on Permafrost, Yakutsk, U.S.S.R.: U.S. National Academy of Sciences, Washington, D.C., p. 257-288.

Bily, C., and Dick, J.W.L., 1974, Natural occurring gas hydrates in the Mackenzie Delta, Northwest Territories: Bulletin of Canadian Petroleum Geology, v. 22, no.`3, p. 340-352.

Bird, K.J., and Magoon, L.B., 1988, Petroleum geology of the northern part of the Arctic National Wildlife Refuge, Northeastern Alaska: U.S. Geological Survey Bulletin 1778, 324 p. 
Carman, G.J., and Hardwick, Peter, 1983, Geology and regional setting of the Kuparuk oil field, Alaska: American Association of Petroleum Geologists Bulletin, v. 67, no. 6, p. 10141031 .

Carter, L.D., Brigham-Grette, Julie, Marincovich, Louie, Jr., Pease, V.L., and Hillhouse, J.W., 1986, Late Cenozoic Arctic Ocean sea ice and terrestrial paleoclimate: Geology, v. 14, p. 675-678.

Cherskiy, N.V., Tsarev, V.P., and Nikitin, S.P., 1985, Investigation and prediction of conditions of accumulation of gas resources in gas-hydrate pools: Petroleum Geology, v. 21, p. 6589.

Collett, T.S., 1983, Detection and evaluation of natural gas hydrates from well logs, Prudhoe Bay, Alaska, Proceedings of the Fourth International Conference on Permafrost, Fairbanks, Alaska: National Academy of Sciences, Washington D.C., p. 169-174.

Collett, T.S., and Bird, K.J., 1988, Freezing-point depression at the base of ice-bearing permafrost on the North Slope of Alaska: Proceedings of the Fifth International Conference on Permafrost, Trondheim, Norway, August 2-5, p. 50-55.

Collett, T.S., Bird, K.J., Kvenvolden, K.A., and Magoon, L.B., 1988, Geologic interrelations relative to gas hydrates within the North Slope of Alaska: U.S. Geological Survey OpenFile Report 88-389, 150 p.

Collett, T.S., Godbole, S.P., and Economides, C.E., 1984, Quantification of in-situ gas hydrates with well logs: Proceedings of the 35th Annual Technical Meeting of the Petroleum Society of CIM, Calgary, Canada, June 10-13, p. 571-582.

Collett, T.S., Kvenvolden, K.A., and Magoon, L.B., 1990, Characterization of hydrocarbon gas within the stratigraphic interval of gas-hydrate stability on the North Slope of Alaska: Applied Geochemistry, v. 5,. p. 279-287.

Davidson, D.W., El-Defrawy, Fuglem, M.O., and Judge, A.S., 1978, Natural gas hydrates in northern Canada: Proceedings of the 3rd International Conference on Permafrost, National Research Council of Canada, v. 1, p. 938-943.

Downey, M.W., 1984, Evaluating seals for hydrocarbon accumulations: American Association of Petroleum Geologist Bulletin, v. 68, no. 11, p. 1752-1763.

Evrenos, A.I., Hearhman, J., and Ralstin, J., 1971, Impermeation of porous media by forming hydrates in-situ; Journal of Petroleum Technology, v. 23, p. 1059-1066.

Franklin, L.J., 1980, In-situ hydrates-a potential gas source: Petroleum Engineer International, November, p.112-122.

Galate, J.W., and Goodman, M.A., 1982, Review and evaluation of evidence of in-situ gas hydrates in the National Petroleum Reserve in Alaska: U.S. Geological Survey unpublished report, Contract No. 14-08-000119148, $102 \mathrm{p}$.

Grantz, Arthur, Holmes, M.L., and Kososki, B.A., 1975, Geologic framework of the Alaskan continental terrace in the Chukchi and Beaufort Seas, in Yorath, Parker, and Glass, eds., Canada's continental margins and offshore petroleum exploration: Canadian Society of Petroleum Geologists Memoir 4, p. 669-700.

Gryc, George, 1988, Geology and exploration of the National Petroleum Reserve in Alaska, 1974 to 1982: U.S. Geological Survey Professional Paper Paper 1399, 940 p.

Hammerschmidt, E.D., 1934, Formation of gas hydrates in natural gas transmission lines: Industrial and Engineering Chemistry, v. 26, p. 851-855.

Hitchon, B., 1974, Occurrence of natural gas hydrates in sedementary basins, in Kaplan, I.R., ed., Natural gases in marine sediments: New York, Plenum Press, p. 195-225.

Holder, G.D., and Hand, J.H., 1982, Multiple-phase equilbrium in hydrates from methane, ethane, propane, and water mixtures: Journal American Institute of Chemical Engineers, v. 28 , no. 3 , p. $440-447$.

Holder, G.D., Malone, R.D., Lawson, W.F., 1987, Effects of gas composition and geothermal properties on the thickness and depth of natural-gas-hydrate zone: Journal of Petroleum Technology, September, p.1147-1152.

Howitt, Frank, 1971, Permafrost geology at Prudhoe Bay, Alaska: World Petroleum, v. 42, no. 8, p. 28-38. 
Hunt, J.M., 1979, Petroleum geology and geochemistry: W.H. Freeman and Company, San Francisco, California, $716 \mathrm{p}$.

Jamison, H.C., Brockett, L.D., and McIntosh, R.A., 1980, Prudhoe Bay--A 10 year perspective, in Halbouty, M.T., ed., Giant oil and gas fields of the decade 1968-1978: American Association of Petroleum Geologists Memoir 30, p. 289-314.

Jenden, P.D., and Kaplan, I.R., 1986, Comparison of microbial gases from the Middle American Trench and Scripps Submarine Canyon--Implications for the origin of natural gas: Applied Geochemistry, v. 1, p. 631-646.

Jones, H.P., and Speers, R.G., 1976, Permo-Triassic reservoirs of Prudhoe Bay Field, North Slope, Alaska, in Braunstein, J., ed., North American Oil and Gas Fields: American Association of Petroleum Geologists Memoir 24, p. 23-50.

Judge, A.S., 1988, Mapping the distribution and properties of natural gas hydrates in Canada: Proceedings of the American Chemical Society Third Chemical Congress of the North American Continent, June 6-7, Toronto, Ontario, Abstract Number 29.

Kvenvolden. K.A., and Grantz, Arthur, 1990, Gas hydrates of the Arctic Ocean region: in Grantz, A., Johnson, L., and Sweeney, J.F., eds., The Ocean region: Boulder, Culorado, Geological Society of America, The Geology of North America, v. L.

Kvenvolden, K.A., and McMenamin, M.A., 1980, Hydrates of natural gas: a review of their geologic occurrences: U.S. Geological Survey Circular 825, 11 p.

Lachenbruch, A.H., 1957, Thermal effects of ocean on permafrost: Geological Society of America Bulletin, v. 68 , no. 11 , p. 1515-1529.

Lachenbruch, A.H., Sass, J.H., Lawver, L.A., Brewer, M.C., Marshall, B.V., Munroe, R.J., Kennelly, J.P., Jr., Galanis, S.P., Jr., and Moses, T.H., Jr., 1987, Temperature and depth of permafrost on the Alaskan Arctic Slope, in Tailleur, I.L., and Weimer, Paul, eds., Alaskan North Slope geology: Bakersfield, California, Pacific Section, Society of

Economic Paleontologists and Mineralogists and the Alaska Geological Society, Book 50, v. 2 , p. $545-558$.

Lachenbruch, A.H., Sass, J.H., Marshall, B.V., and Moses, T.H., Jr., 1982, Permafrost heat flow, and the geothermal regime at Prudhoe Bay, Alaska: Journal of Geophysical Research, v. 87, no. B11, p. 9301-9316.

Lerand, M., 1973, Beaufort Sea, in McCrosisan, R.G., ed., Future petroleum provinces of Canada--Their geology and potential: Canadian Society of Petroleum Geologists Memoir 1, p. 315-386.

Lewin and Associates, Inc., 1983, Handbook of gas hydrates properties and occurrences: Report for U.S. Department of Energy, Office of Fossil Energy, Morgantown Energy Technology Center, Morgantown, West Virginia, Contract No. DE-AC21-82MC19239, 234 p.

Magoon, L.B., and Claypool, G.E., 1985, Alaska North Slope oil-rock correlation study: American Association of Petroleum Geologists Special Studies in Geology 20, 682 p.

Makogon, Y.F., Trebin, F.A., Trofimuk, A.A., Tsarev, V.P., and Cherskiy, N.V., 1972, Detection of a pool of natural gas in a solid (hydrate gas) state: Doklady Academy of Sciences U.S.S.R., Earth Science Section, v. 196, p. 197-200.

Makogon, Y.F., 1981, Hydrates of natural gas: Tulsa, Penn Well Publishing Company, 237 p.

Masters, C.D., Attanasi, E.D., Dietzman, W.D., Meyer, R.F., Mitchell, R.W., and Root, D.H., 1987, World resources of crude oil, natural gas, natural bitumen, and shale oil: World Petroleum Congress Proceedings, 12 th, v. 5, p. 3-2\%.

Morgridge, D.L., and Smith, W.B., 1972, Geology and discovery of Prudhoe Bay Field, eastern Arctic Slope, in King, R.E., ed., Stratigraphic Oil and Gas Fields-Classification, Exploration Methods, and Case Histories; American Association Petroleum Geologists Memoir 16, p. 489-501.

Osterkamp, T.E., 1975, Structure and properties of ice lenses in frozen ground: Report No. UAGR233, Geophysical Institute, University of Alaska, Fairbanks, Alaska, 36 p.

Osterkamp, T.E., and Payne, M.W., 1981, Estimates of permafrost thickness from well logs in northern Alaska: Cold Regions Science and Technology, v. 5, p. 13-27. 
Potential Gas Committee, 1981, Potential supply of natural gas in the United States (as of December 31, 1980): Potential Gas Agency, Colorado School of Mines, Golden, Colorado, $199 \mathrm{p}$.

Pratt, R.M., 1979, Gas hydrate evaluation and recommendations, National Petroleum Reserve, Alaska: U.S. Geological Survey Special Report TC-7916, 27 p.

Schoell, Martin, 1983, Genetic characterization of natural gases: American Association of Petroleum Geologists Bulletin, v. 67, no. 12, p. 2225-2238.

Seifert, W.K., Moldowan, J.M., and Jones, J.W., 1979, Application of biological chemistry to petroleum exploration: 10th World Petroleum Congress, p. 425-440.

Sloan, E.D., 1990, Clathrate hydrates of natural gases: Marcel Dekker, Inc., New York, New York, $641 \mathrm{p}$.

Tailleur, I.L., and Weimer, Paul, 1987, Alaskan North Slope geology: Bakersfield, California, Pacific Section, Society of Economic Paleontologists and Mineralogists and the Alaska Geological Society, Book 50, v. 1, 874 p.

Werner, M.R., 1987, Tertiary and Upper Cretaceous heavy oil sands, Kuparuk River area, Alaskan North Slope, in Tailleur, I.L., and Weimer, Paul, eds., Alaskan North Slope geology: Bakersfield, California, Pacific Section, Society of Economic Paleontologists and Mineralogists and the Alaska Geological Society, Book 50, v. 1, 109-118.

Yousif, M.H., Abass, H.H., Selim, M.S., and Sloan, E.D., 1988, Experimental and theoretical investigation of methane gas hydrate dissociation in porous media: Proceedings of the 63rd Annual Technical Conference and Exhibition of the Society of Petroleum Engineers, October 2-5, Houston, Texas, p. 571-583.

Zoller, W.A., 1984, Determine pore pressure from MWD gamma ray logs: World Oil, March، p. 97-102. 

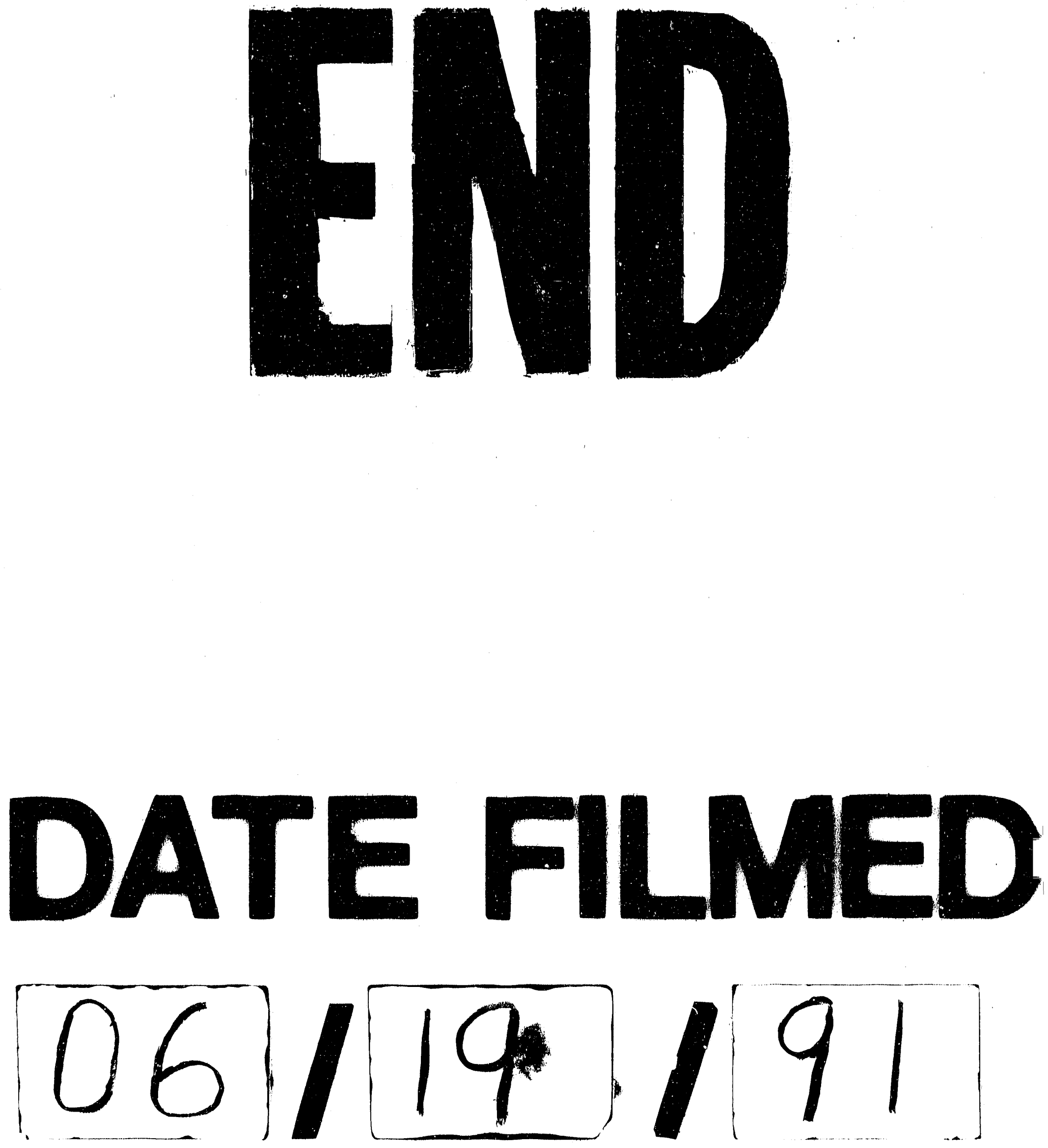